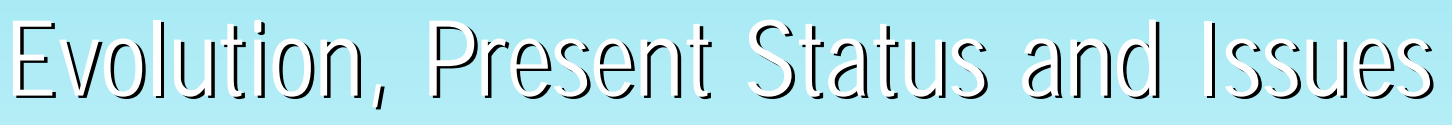

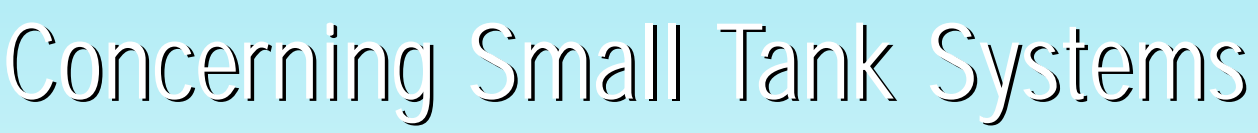

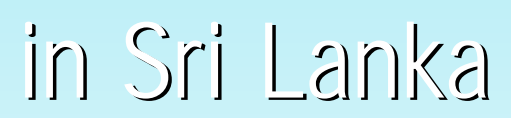

C. P. Pasalookke, fr. Saktrij yadj yel

and Asoka Dials Weerasinghe

Intern ational 
Evolution, Present Status and Issues Concerning Small Tank Systems in Sri Lanka 



\title{
Evolution, Present Status and Issues \\ Concerning Small Tank Systems in Sri Lanka
}

\author{
C. R. Panabokke \\ R. Sakthivadivel \\ and
}

Asoka Dias Weerasinghe 
IWMI receives its principal funding from 58 governments, private foundations and international and regional organizations known as the Consultative Group on International Agricultural Research (CGIAR). Support is also given by the Governments of Ghana, Pakistan, South Africa, Sri Lanka and Thailand.

The authors: C. R. Panabokke has provided leadership to land and water management research in Sri Lanka for over 35 years and is a Research Fellow of the International Water Management Institute (IWMI), Colombo, Sri Lanka. R. Sakthivadivel is a Principal Researcher at IWMI. Asoka Dias Weerasinghe is a Freelance Consultant.

Panabokke, C. R. ; R. Sakthivadivel; A. D. Weerasinghe. 2002. Evolution, present status and issues concerning small tank systems in Sri Lanka. Colombo, Sri Lanka: International Water Management Institute.

/ irrigation management / water management / water distribution / tank irrigation / watersheds / irrigation design / maintenance / farming systems / governmental interrelations / small-scale systems / Sri Lanka /

ISBN: 92-9090-477-1

Copyright @ $\odot$ 2002, by IWMI. All rights reserved

Responsibility for the contents of this publication rests with the authors. 


\section{CONTENTS}

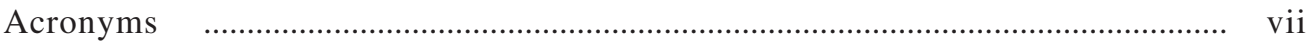

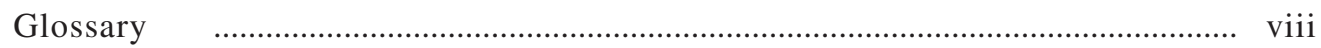

Technical Terms ............................................................................................... ix

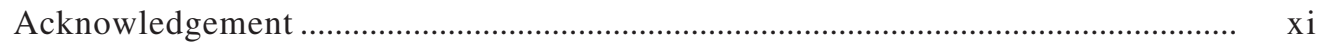

Chapter 1 Physical Setting, Distribution Patterns,

Cascade Systems and Size-class Distribution .................................... 1

Chapter 2 Past Evolution, Causes for Abandonment and Recent History ............. 10

Chapter 3 Rationale for Selection of Five Representative Small Tank

Cascade Systems: Their Main Characteristics, Present

Status and Uses ............................................................................. 16

Chapter 4 Design of Tank Cascade Systems, The Hydro System,

Maintenance and Tank Use ................................................................. 32

Chapter 5 Institutional Management and Integration with

Local Farming Systems .................................................................. 40

Chapter 6 Recent Changes Due to Government Interventions ............................. 47

Chapter 7 Present and Future Issues Facing Small Tank

Cascade Systems ......................................................................... 54

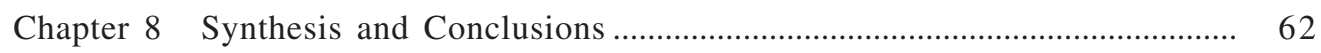

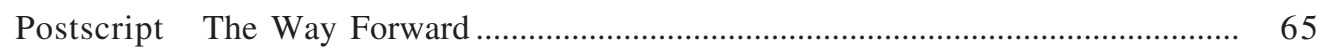

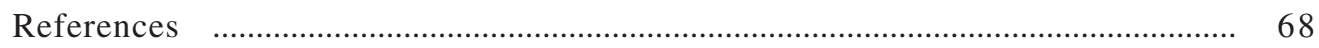

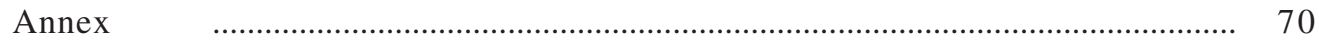




\section{Figures}

Figure 1. Main agro-climatic zones of Sri Lanka ............................................ 2

Figure 2. Islandwide distribution pattern of small tanks ................................. 4

Figure 3. Schematic representation of a small tank cascade system ............... 6

Figure 4. Size-class distribution of small tanks in four districts ....................... 9

Figure 4.1. A cross-sectional view of a present-day village tank ...................... 11

Figure 5. Locations of the five selected modlal cascades ............................... 17

Figure 6. Agro-ecological regions of the dry and intermediate zones ........... 19

Figure 7. Schematic representation of Pihimbiyagollawa, cascade 1 ............. 22

Figure 8. Schematic representation of Mahakanumulla, cascade 2............... 24

Figure 9. Schematic representation of Maha Naneriya, cascade $3 \ldots \ldots \ldots \ldots \ldots . . . . . .26$

Figure 10. Schematic representation of Maha Girilla-Olupeliyawa, cascade 4

Figure 11. Schematic representation of Bodagama, cascade 5 ......................... 30

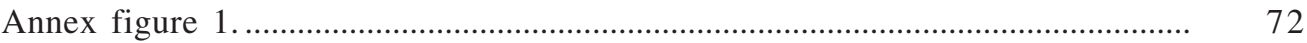

\section{Tables}

Table 1 Number of operational and abandoned small tanks within each province

Table 2. Number of operational tanks in four districts surveyed by DAS

Table 2.1. Size-class distribution of small tanks in four districts

Table 3. The percentages of functioning and abandoned tanks by province

Table 4. Main characteristics of each cascade.

Table 5. Size-class distribution of tanks within each cascade

Table 6. Organizational changes in management of small irrigation systems

Table 7. Extents of Puranawela and Akkarawela in sample tank

Table 8. Population figures for cascade 1

Table 9. Population figures for cascade 2 


\section{Acronyms}

ABMP Agriculture Base Map Project of the Survey Department of Sri Lanka ADB Asian Development Bank

CC Cultivation Committee

COWI A foreign consultancy firm on groundwater

DAS Department of Agrarian Services

DO Divisional Officer

EP Eastern Province

FAO Food and Agriculture Organization of the United Nations

FO Farmer Organization

GA Government Agent

IFAD International Fund for Agricultural Development

IRDP Integrated Rural Development Project

IWMI International Water Management Institute

KM Kanna Meeting

MASL Mahaweli Authority of Sri Lanka

NCP North Central Province

NIRP National Irrigation Rehabilitation Project

NORAD Norwegian Agency for Development Cooperation

NP Northern Province

NWP North Western Province

NWS\&DB National Water Supply \& Drainage Board

OFCs Other Food Crops

PRDP Participatory Rural Development Project

SP Southern Province

TCEO Territorial Civil Engineering Organization

TO Technical Officer

VC Village Council

VIRP Village Irrigation Rehabilitation Project

WHO World Health Organization 


\section{Glossary}

Akkarawela

Bethma

Bisokotuwa

Chena

Gamarala

Gamsabhawa

Gam Udawa

Gangoda

Godawala

Govi Karaka Sabha

Janasaviya

Kanna Meeting

Kuluwewa

Liyadda

Maha

Maha Vidyala

Mahawamsa

Maranadhara Samithi

Mudalali

Olagama

Palaka Lekam

Pangukarayas

Puranawela

Rajakariya

Salaris

Velvidane

Welyaya

Wewa

Yala

Yaya Niyamaka (YK)/

Yaya Niyojitha (YN)
New leasehold paddy fields

Agreed rules for sharing water in scarce situations

Cistern type masonry sluice of ancient large tanks

Shifting dry-land cultivation

Village elder/headman

Village council

Government initiative for providing shelter for the needy

Highland

Shallow depression that can hold water

Farmer committee council

Government welfare program for poverty alleviation

Pre-seasonal meeting of farmers

Silt-trapping small tanks

On-farm irrigated basin with small bunds

Major cultivation season (associated with the longer rainy season)

High school

Ancient text on Sri Lankan history

Funeral assistance committee

Trader cum money lender/middleman

Tanks under which no permanent settlement exists

Administrative secretary

Shareholders

Old paddy fields

Ancient custom of compulsory labor for tank maintenance

Sinhala equivalent for salary

Traditional irrigation headman

Tract of paddy field

Tank

Minor cultivation season (shorter rainy season)

Persons who are in charge of a tract in the tank command (working under Velvidane) 


\section{Technical Terms}

DL1, DL5, IL3

EC

Regolith

RKP

ER

SAR

FSL

Form Index
Agro-ecological Regions (AER)

Electrical Conductivity

Decomposing Rock Layer

Rock Knob Plain (landform type)

Erosion Remnant (landform type)

Sodium Absorption Ratio

Full Supply Level

Ratio of length to width 


\section{Acknowledgement}

The authors acknowledge the efforts put in by Dr. Randolph Barker in critically reviewing the manuscript and in providing assistance to bring out this publication in a book format. We also acknowledge the critical review made by Dr. M. U. A. Tennakoon and comments made by J. Alwis. 


\section{CHAPTER 1}

\section{Physical Setting, Distribution Patterns, Cascade Systems and Size-class Distribution}

\subsection{Physical Setting}

Small tanks in Sri Lanka are those having an irrigated command area of 80 ha $(1$ ha $=2.47$ acres) or less, as defined by the Agrarian Services Act No. 58 of 1979. They have also been referred to as "village tanks" in official records and published literature, but the term small tank is retained throughout this publication. A glance at the 1 inch to 1 mile $(1: 63,360)$ topographical maps of the Survey Department shows the physical location of these small tank systems, which are usually located within the first or second order inland valleys, or the ephemeral streams of the dry zone of Sri Lanka.

The dry zone of Sri Lanka (figure 1) is located within the lowest peneplain of the island and consists of a gently undulating to undulating land surface, or a "planation" surface that is characterized by the occurrence of a large number of small inland valleys. A topography of this type is ideal for the construction of such small reservoirs or tanks, especially when the underlying basement rock is highly impervious and the overlying weathered rock and soil are usually shallow to moderately deep. The mean annual rainfall of the dry zone is less than $1,250 \mathrm{~mm}(1 \mathrm{~mm}=0.034 \mathrm{inch})$, and the main rainfall season is from October to January when around 80 percent of the annual rainfall is received. Because of the high yearly variation, a 75 percent probability value of annual rainfall provides a more reliable statistic of rainfall expectancy. This amounts to approximately $800 \mathrm{~mm}$ for most of the dry zone in Sri Lanka. During the 5-month period from May to September, the dry zone falls within the rain shadow of the southwest monsoon, and this results in a protracted dry period with strong desiccating winds and daily evaporation rates of between $5.5 \mathrm{~mm}$ to $7.0 \mathrm{~mm}$. The annual average evaporation in the dry zone is between $1,700 \mathrm{~mm}$ and $1,900 \mathrm{~mm}$, which exceeds the average annual rainfall, implying water stress during this part of the year.

Small tank surface storage systems provided the lifeblood for human settlement and existence in these areas. The highly variable nature of rainfall combined with high evaporation rates, for a greater part of the year, and the paucity of readily accessible groundwater in this hard rock region meant that no stable human settlement would have been possible without recourse to the storage of surface water in small tanks as described by Abeyratne (1956) and Ievers (1899).

These small tank or village tank systems, as they are also referred to, were constructed in ancient times, mostly during the medieval period, and were the centers of ancient village 
Figure 1. Main agro-climatic zones of Sri Lanka.

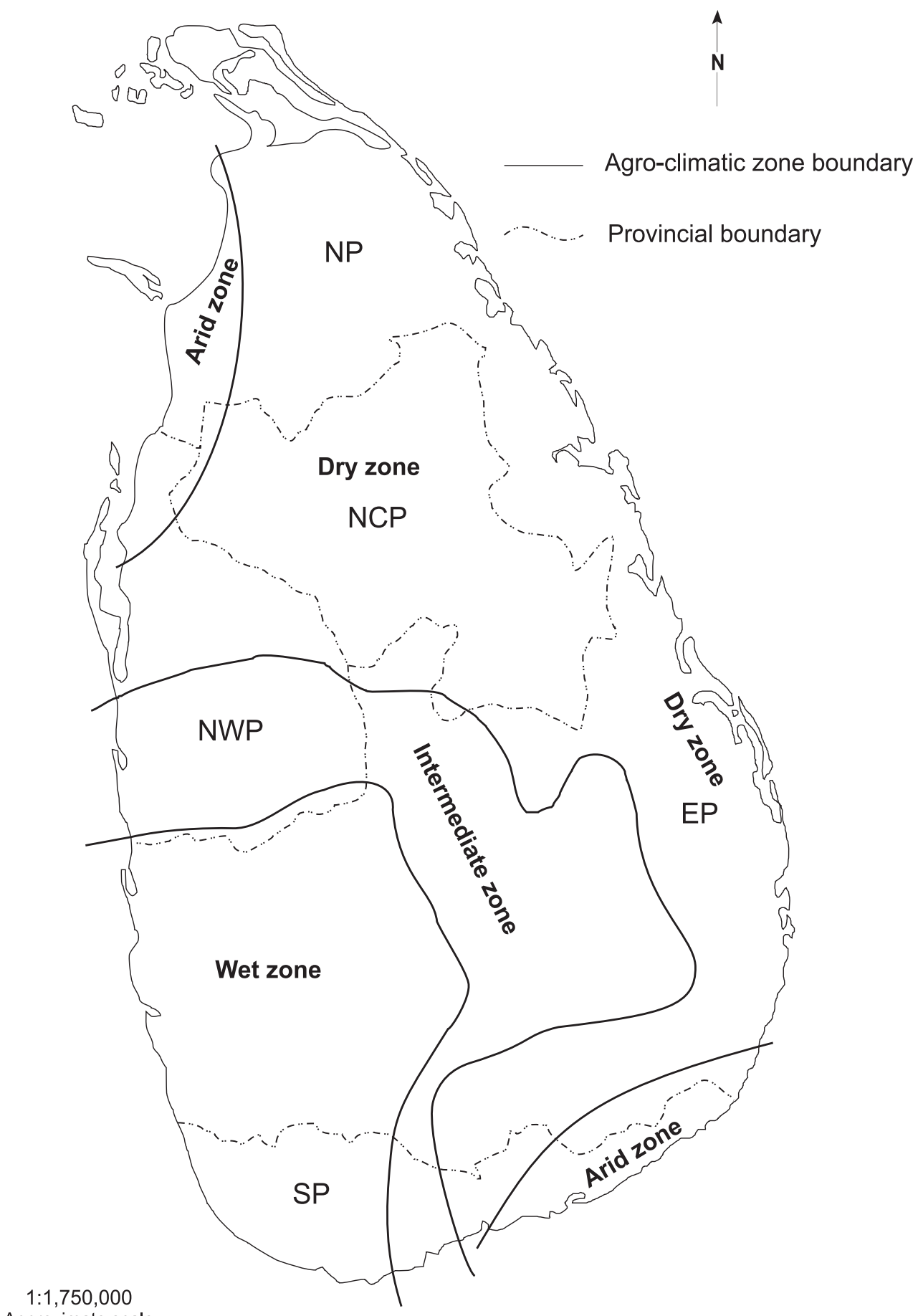

Approximate scale 
settlements. The center of the dry zone village is the tank and houses are grouped on one or both sides of the tank on the relatively higher elevation around the tank bund. The wells for domestic water, which tap the shallow phreatic groundwater table, are located within this homestead area. The irrigable land below the tank bund is located along the main axis of the inland valley. Rainfed upland crops are grown on the unirrigable slopes of the upland under a system of shifting or chena cultivation.

\subsection{Distribution Patterns}

A general overview of the distribution pattern of small tank systems across the whole of the dry zone could be obtained from the map developed by Cook (1935) which is reproduced in figure 2. This map depicts the number of tanks occurring within each of the 1 inch to 1 mile topo sheets that make up the whole island. A similar scale map of the respective provincial boundaries is also shown in figure 1. It can be observed from these maps that the highest tank density occurs within the southern segment of the North Western Province (NWP), and this is followed by the central segment of the North Central Province (NCP). Since each topo sheet shown in this figure covers an extent of $950 \mathrm{~km}^{2}\left(1 \mathrm{~km}^{2}=0.39\right.$ square miles), the presence of 800 tanks within a topo sheet would indicate a tank density of approximately one tank per $1.2 \mathrm{~km}^{2}$ in the high density region, and approximately one tank per $12.0 \mathrm{~km}^{2}$ in the low density region of the Eastern Province (EP). The figures given by Cook (1935) would have been based on the information provided by the 1 inch topo sheets of that period, which included both major and medium sized tanks.

In the present study, a count was made of both presently operating and abandoned small tanks in each of the 70 river basins that make up the dry zone. The locations of these 70 basins are given in annex figure 1 . This count was made using the most recently published 1 inch to 1 mile topo sheets of the Survey Department of Sri Lanka, together with the 1:50,000 scale Agricultural Base Maps Project (ABMP) maps provided in 1984 by the Survey Department. A cross check was made in respect of four topo sheets ( 2 in the NCP, 1 in the NWP, and 1 in the Southern Province [SP]) by stereoscopic analysis of the more recently available 1:25,000 scale aerial photographs. A detailed statement of the total number of small tanks within each river basin and the number of river basins within each province is given in annex 1. A summary statement of the number of both operational and abandoned small tanks in each province is given in table 1 .

As can be seen from the above table taken in conjunction with figures 1 and 2, the highest number as well as the highest density of small tanks are in the NWP and NCP. At the same time, the highest proportion of abandoned tanks is in the SP, lower Uva (southeastern province) and EP, followed by the Northern Province (NP) and the NCP.

In general, the average tank density is one tank per $2.6 \mathrm{~km}^{2}$ for the NP, NCP and SP. For the NWP the density is around one tank per $1.2 \mathrm{~km}^{2}$. This conforms to both the nature of the overall rainfall regime as well as the nature of the geomorphology of the region.

A more detailed depiction of small tank systems occurring within each of the nine watersheds of Rajarata (NCP), on a scale of 1:250,000, is given in The Small Tank Cascade Systems of the Rajarata (Panabokke 1999). It also depicts the boundaries of the 457 small tank cascade systems that are within these 9 river basins. 
Figure 2. Islandwide distribution pattern of small tanks.

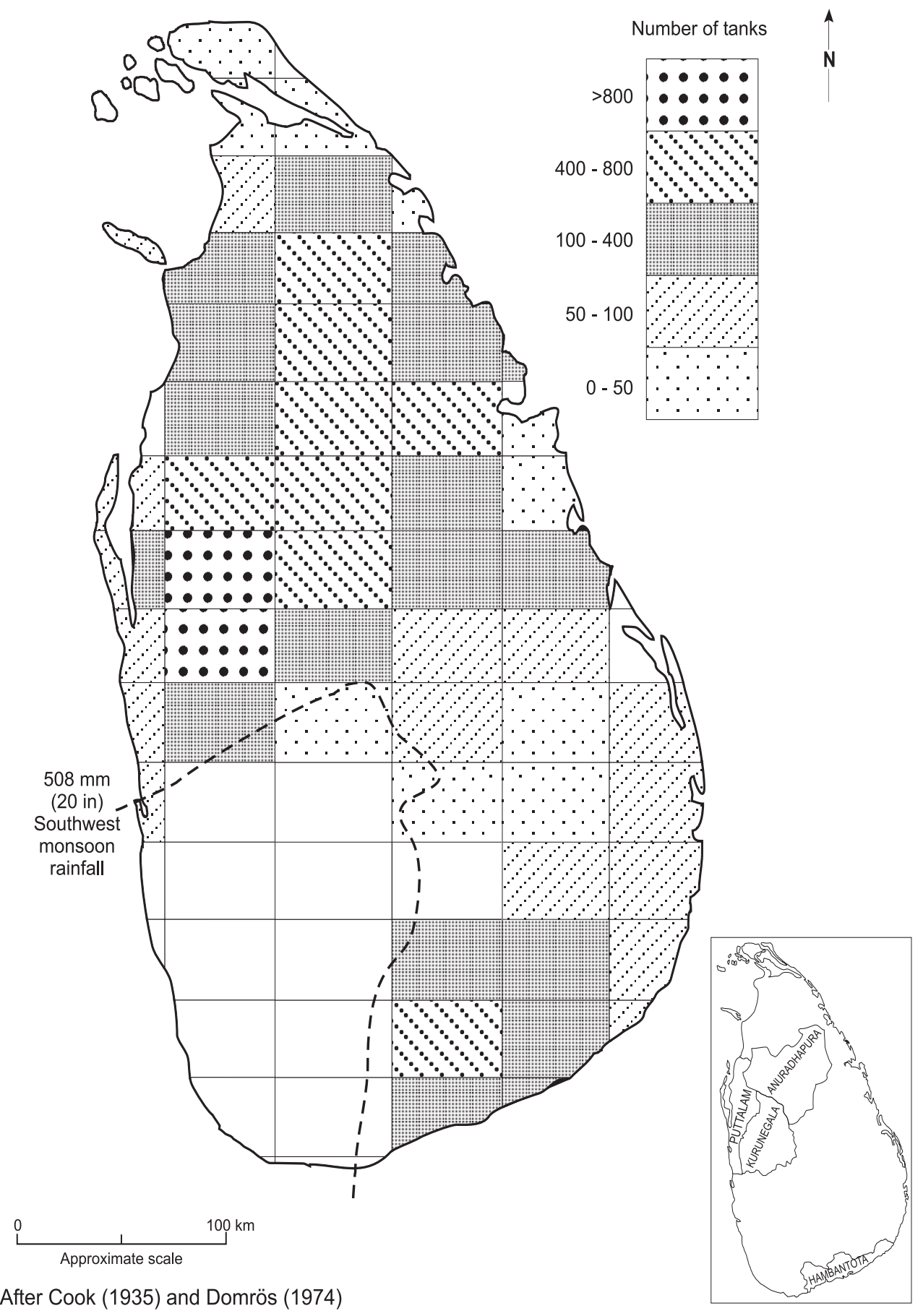

After Cook (1935) and Domrös (1974) 
Table 1. Number of operational and abandoned small tanks within each province.

\begin{tabular}{lccr}
\hline Province and area $\left(\mathrm{km}^{2}\right)$ & \multicolumn{2}{c}{ Number of small tanks } & Total \\
\cline { 2 - 3 } Operating & Abandoned & \\
\cline { 2 - 3 } Northern 3,709 & 608 & 816 & 1,424 \\
North Central 10,365 & 2,095 & 1,922 & 4,017 \\
North Western 7,760 & 4,200 & 2,273 & 6,473 \\
Southern 2,849* & 653 & 757 & 1,410 \\
Lower Uva 2,901* & 16 & 543 & 559 \\
Eastern (South of Mahaweli) 3,885* & - & 1,017 & 1,017 \\
Eastern (North of Mahaweli)* & 48 & 425 & 473 \\
\hline Total & 7,620 & 7,753 & 15,373 \\
\hline
\end{tabular}

*Includes only the dry zone part of the province.

Note: The data is based on 1995 Department of Agrarian Services (DAS) data bank and 1982 ABMP maps.

The Sri Lanka Wewas and Reservoirs Album (3 volumes) published under the direction of Ratnatunga (1979), by the Freedom from Hunger Campaign, Food and Agriculture Organization of the United Nations (FAO) contains the most comprehensive and up-to-date depiction of all existing and abandoned tanks of all sizes. One of the chief advantages of this publication is that it uses standard 1 inch to 1 mile topo sheets of the Survey Department and the systematic numbering of tanks within each of the country's river basins. These three volumes cover the NCP, NWP and SP of the country and exclude the NP and EP.

\subsection{Cascade Systems}

A schematic representation of a typical small tank cascade system is shown in figure 3 . The main elements that make up a cascade, namely, (a) the watershed boundary of the mesocatchment, (b) the individual micro-catchment boundaries of the small tanks, (c) the main valley and side valleys are shown in the same figure. A close examination of the 1 inch to 1 mile topo sheets of the Survey Department covering the dry zone regions would show that more than 90 percent of the small tank systems are clustered into cascades. Each of these cascades form a distinct small watershed or meso-catchment ranging in extent from 5 to 10 square miles (13-26 $\left.\mathrm{km}^{2}\right)$ with a modal value of around 8 square miles.

The maps of the natural drainage pattern at a scale of 1:63,360 show that all cascades are located within either a second order inland valley, or a first order ephemeral stream. It should also be borne in mind that there is no dry season flow in these ephemeral streams from February to October except for the first order ephemeral streams, which get reactivated for a very short period with the March-April rains. These small tank cascade systems, constructed in ancient times, could be considered as unique irrigation systems with a distinctive assembly of land uses. The land and water management practices that were refined and perfected over several centuries in order to match the capricious nature of rainfall, along with the special geomorphological attributes of the landscape, led to a system of irrigation development described as a "cascading system" by Madduma Bandara (1985).

A cascade, according to the definition by Madduma Bandara (1985, is a "connected series of tanks organized within the meso-catchments of the dry zone landscape, storing, 
Figure 3. Schematic representation of a typical small tank cascade system.

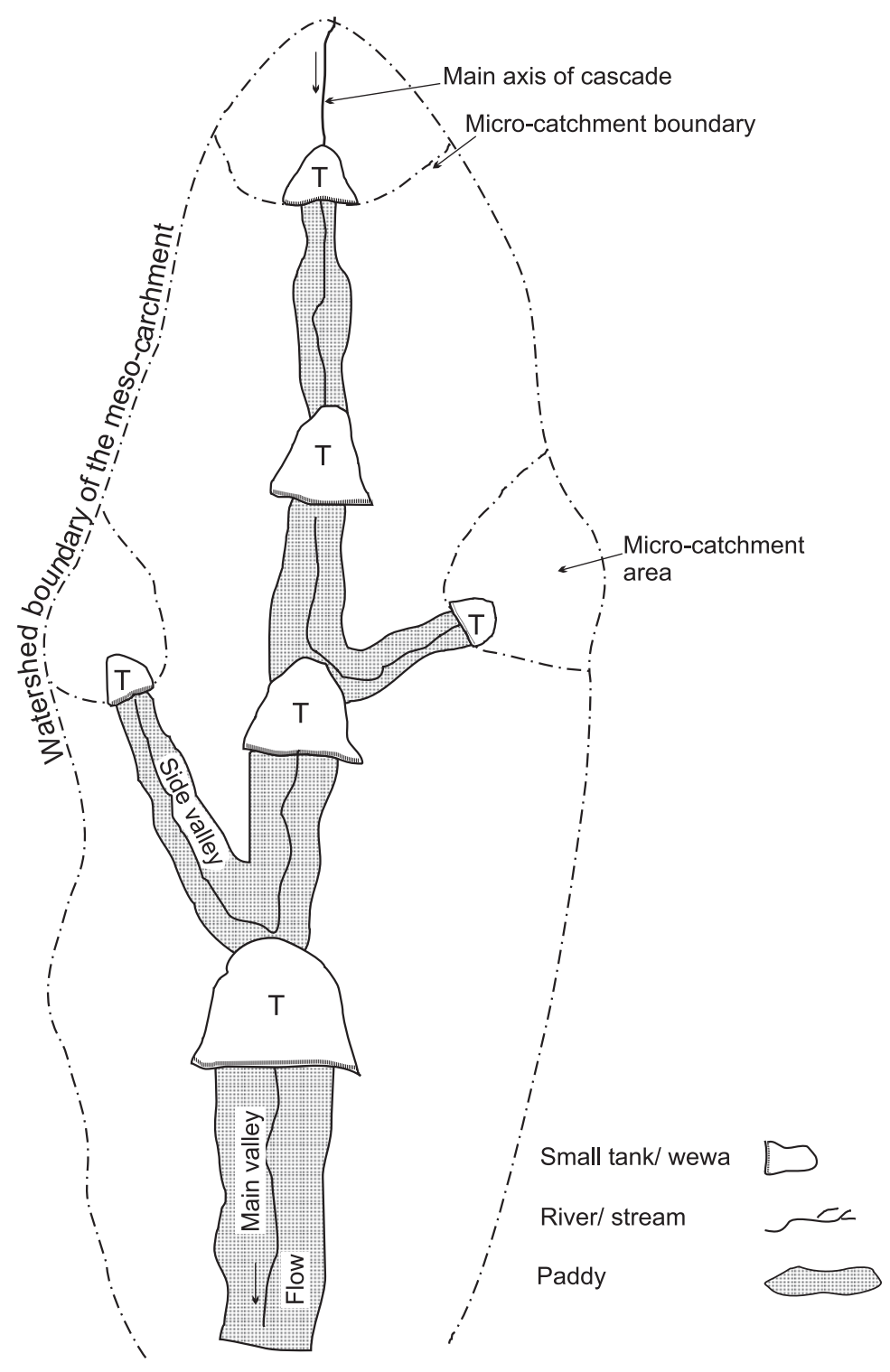


conveying and utilizing water from an ephemeral rivulet." Some of the more important indigenous and traditional understandings of small tank cascade systems have been described and discussed by Tennekoon (1995). He observes that "one of the cardinal strategies adopted in tank construction in a cascading valley seems to be the strict adherence to (a) having an adequate volume of water in every tank of the settled village in a cascading valley even in a year of below-average rainfall (b) instituting a regulated flow of water from one tank to another downstream, avoiding a sudden influx of large volumes of water in order to minimize the risks to tank bund breaching and (c) having some reservoirs in reserve as Olagama ${ }^{1}$ tanks for water table stabilization and Godawala ${ }^{2}$ as water holes for village cattle and wild animals." He also concludes that the cascade concept was well entrenched in the minds of the ancient farmers and water resources managers.

Ithakura and Abernethy (1993) made the following observations: "In Sri Lanka what are called tank cascade irrigation systems have developed as ultimate stock-type irrigation systems. These systems are interconnected storage and regulating reservoirs, which serve multiple functions of resource management including irrigation, domestic supply, water for livestock and subsurface water for perennial cropping. Some of these tanks have very long histories which date back to over a thousand years, and were once the backbone of an ancient hydraulic civilization which flourished in the north central part of the country."

Small tanks in a tank cascade are hydrologically interlinked and if the hydrology of one or a few tanks is altered by increasing its storage capacity or expanding the irrigated command area or by diverting water elsewhere from the cascade, the entire hydrology of the cascade is changed. If the cascade is well endowed with water, the resulting effect may not be very significant, but if water is limited in relation to total demand, there may be serious implications in terms of water availability for downstream users. This means that the hydrology of an entire cascade needs to be assessed and understood in order to make the best use of available water resources within the cascade. It is essential to recognize this before any intervention to any individual tank in the cascade is contemplated.

Irrigated agriculture under small tanks of these cascades form only one component of the activities of a majority of the farmers. Other activities such as chena cultivation in the uplands, homestead gardening and livestock rearing together with irrigated rice make up their livelihood. A more recent development over the last decade has been the cultivation of highvalue crops during the dry season by utilizing shallow groundwater, which is drawn from large diameter agrowells located in the lower aspects of the landscape.

\subsection{Size-class Distribution}

The Water Management Division of the Department of Agrarian Services (DAS) has been conducting a minor irrigation data collection survey since 1990 in 17 of the 25 administrative districts, with the exception of the NP and EP. The data collected and updated in 1997 in respect of the presently operating small tanks for four districts (figure 2) where such surveys have been completed is given in table 2 and table 2.1 .

\footnotetext{
${ }^{1}$ Tanks under which no permanent settlement exists.
}

${ }^{2}$ Shallow depressions which can hold water. 
The size-class distribution for each district based on the command area for each sizeclass is given in table 2.1.

Table 2. Number of operational tanks in four districts surveyed by DAS.

\begin{tabular}{lc}
\hline District & $\begin{array}{c}\text { Number of presently } \\
\text { operating small tanks }\end{array}$ \\
\hline Anuradhapura & 2,481 \\
Kurunegala & 4,482 \\
Puttalam & 752 \\
Hambantota & 433 \\
\hline Total & 8,148 \\
\hline
\end{tabular}

Table 2.1. Size-class distribution of small tanks in four districts.

\begin{tabular}{llrrrrrr}
\hline District & \multicolumn{6}{c}{ Size-class of command area (ha) } \\
& & $<$ & $6-10$ & $10-20$ & $20-30$ & $30-40$ & $>40$ \\
\hline Anuradhapura & Number & 420 & 520 & 826 & 289 & 177 & 241 \\
& Percentage & 17 & 21 & 33 & 12 & 7 & 10 \\
Kurunegala & Number & 2,873 & 667 & 654 & 153 & 50 & 45 \\
& Percentage & 64 & 15 & 15 & 3 & 1 & 2 \\
Puttalam & Number & 339 & 152 & 184 & 33 & 18 & 26 \\
& Percentage & 45 & 20 & 24 & 5 & 2 & 4 \\
& Hambantota & 172 & 82 & 106 & 42 & 12 & 19 \\
& Number & & & 24 & 3 & 4 \\
\hline
\end{tabular}

In table 2 and figure 2 around 50 percent of the small tanks in the Anuradhapura district fall within the 6 ha ( 1 ha $=2.47$ acre) to 20 ha command area size-class, while in the adjacent Kurunegala district only 30 percent of the small tanks fall within the same range of 6 ha to 20 ha size-class. At the same time, almost 65 percent of the small tanks in the Kurunegala district fall within the size-class of less than 6 ha command area. This implies that there is a preponderance of the smaller size-class tanks of less than 6 ha size command area in the Kurunegala district compared to a preponderance of comparatively larger size-class tanks of more than 10 ha command area in the Anuradhapura district. This is also qualitatively confirmed when examining the size-class distribution of the waterspread areas of small tanks, as can be seen in the 1 inch topo sheets of the two districts. The higher rainfall experienced in the Kurunegala district together with the higher drainage density of the landscape in this region permits the construction of a larger number of small tanks.

In respect of the Puttalam and Hambantota districts, it could be observed from table 2.1 that around 40 percent of the small tanks fall within the size-class of less than 6 ha command area. Furthermore, around 45 percent of the small tanks in both districts fall within the 6 ha to 20 ha command area size-class. It should be noted that both these districts are, for the most part, located within the drier or semi-arid parts of the dry zone. It is the limited 
amount of runoff generated from the lower rainfall that primarily accounts for the preponderance of the smaller size tanks in these two districts.

It could also be observed from table 2.1 that while the Anuradhapura district has around 30 percent of small tanks with a command area of more than 20 ha, the corresponding figure for the Hambantota district is around 15 percent, for the Puttalam district around 10 percent, and for the Kurunegala district around 5 percent.

The size-class distribution of tanks of the different command areas in respect of all four districts is also shown in figure 4. This figure shows that the dominant size-class of tanks in the Anuradhapura district falls within the 10-20 ha size command area, while the dominant size-class for the Kurunegala district is less than 6 ha size command area. In the case of the Hambantota and Puttalam districts, there are two dominant size-classes, the 0-6 ha and the 10-20 ha size command areas.

Figure 4. Size-class distribution of small tanks in four districts.

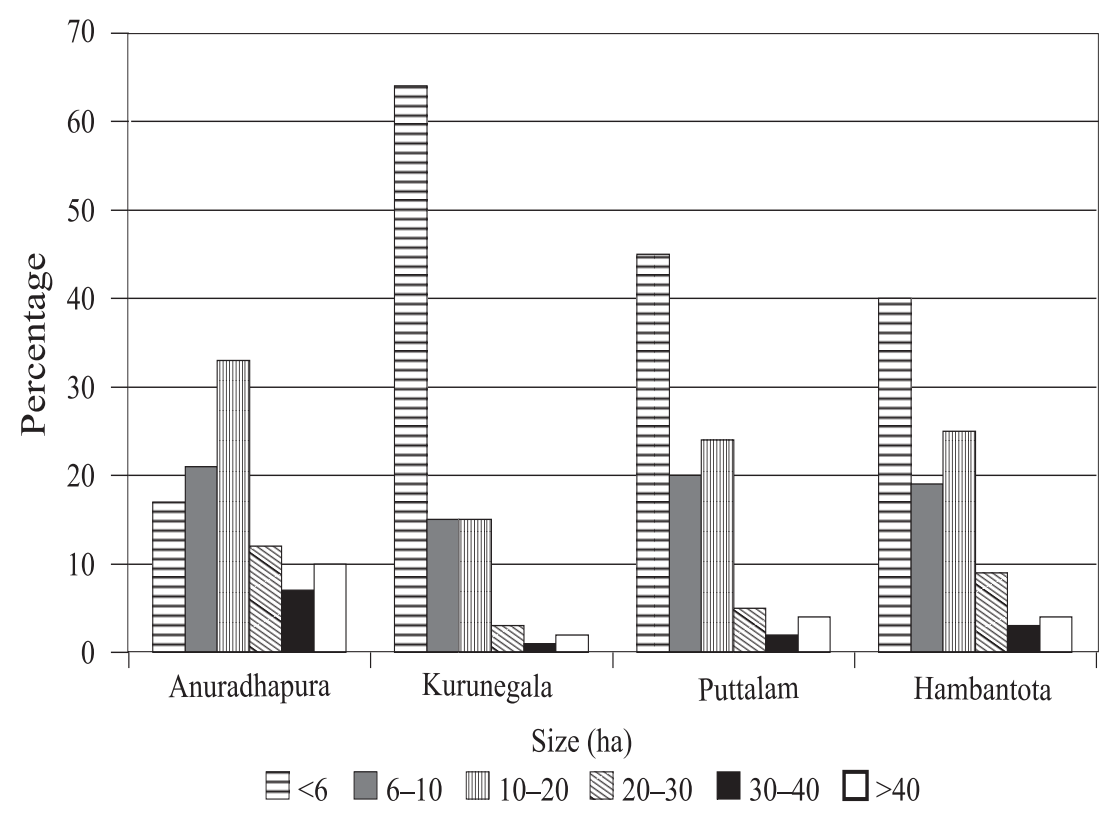




\section{CHAPTER 2}

\section{Past Evolution, Causes for Abandonment and Recent History}

\subsection{Past Evolution}

There are a few reported studies that have been carried out on aspects of the past evolution of small tanks. Some historical references indicate that these small tank systems have been in existence since the medieval period (Tennakoon 1995).

According to Mendis (1986), the earliest rock inscriptions of this country belong to 300 B.C. and these inscriptions indicate that practically most parts of the island, especially the dry zone regions had been occupied, in varying degrees, by about 300 or 200 B.C. Studies by Parker (1907) and Brohier (1935) mainly focused on the ancient larger irrigation systems, which are well known for their very distinctive features like hydraulic design and construction. Needham (1971) has also commented on some aspects of the major irrigation constructions.

The earliest medium-scale irrigation reservoir that could be identified with certainty is the present Basavakkulama tank with a water spread of 107 ha, built around 300 B.C. All the well known ancient major irrigation works in this country are known to have been constructed after this datum period (Brohier 1935).

Other indirect and circumstantial evidence points to the fact that these small-scale village irrigation reservoirs were the precursors to the larger and more impressive network of irrigation systems that evolved later and were constructed during the reign of various rulers up to 1200 A.D. From all accounts it is clear that the spread of these small tank irrigation systems would have taken place concurrent to the construction of the major irrigation systems. However, while the construction of these major works was controlled and directed by the kings and other higher echelons of the irrigation bureaucracy, the small village tank systems were initiated and constructed by small village communities by communal effort throughout a period of approximately 1.500 years.

During the present study, it was observed that a majority of the small tanks that were hydrologically well endowed and were also less susceptible to breaching during major rainfall events, had, according to oral village tradition, been in continuous existence and use from the period of King Valagambahu (approximately 300-400 B.C.). These would have started as small village settlements around small tanks, which gradually increased in size in response to increasing population. 
The technology of construction and maintenance of these small tanks was fairly simple and straightforward and easily within the capability of village labor resources as well as construction skills (a cross-sectional view of a present-day village tank is shown in figure 4.1). Going by the fact that by 400 or 500 A.D. the design and construction of the

Figure 4.1. A cross-sectional view of a present-day village tank.

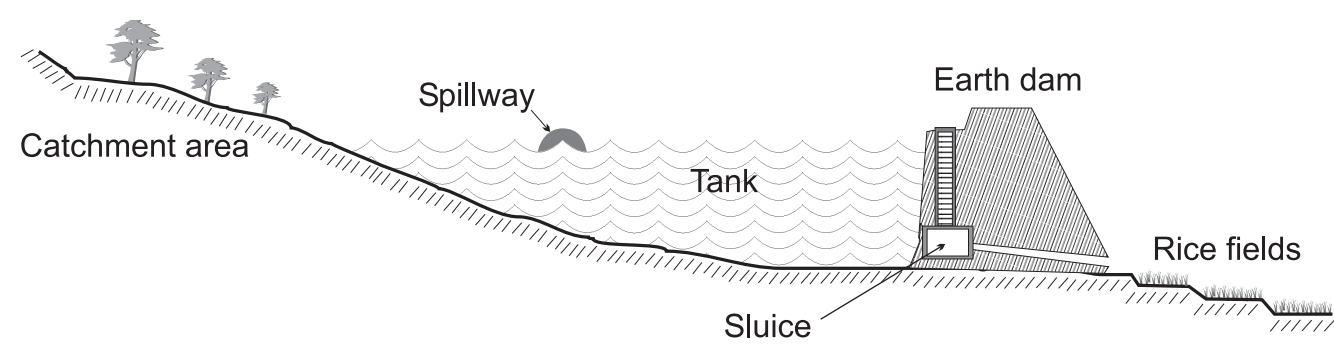

major irrigation networks had attained a high level of technical sophistication, it could be surmised that the technology of small tank design and construction could also have attained a high level of maturity by the same period, or even long before this period.

Based on historical commentaries such as the mahawamsa (ancient text on Sri Lankan history), it could be fairly reliably inferred that the construction and settlement of 15,000 smaller village tanks (identified today) would have taken place at different periods in the different regions of the dry zone throughout a long period of time, extending up to 1200 and 1300 A.D. Thus, it can be assumed that by the 1300 A.D. almost all of these 15,000 small tanks were in some state of existence and were either fully or partly operational. With the decline of the central governments and the major irrigation systems from 1300 A.D. onwards, there was a major shift in the dry zone population to the wet zone up to around 1500 A.D. While there was a decline and decay of the major irrigation systems of the dry zone from the 1200 A.D. onwards, these small tank systems continued in varying degrees of operation and utilization, on their own internal organizational strengths.

The investment of village labor in the successful innovation and construction of these village tanks resulted in the development of a strong source of common property that ensured the maintenance and stability of these small village tanks over hundreds of years. Through this, they also developed a high degree of resilience to various stresses compared to the larger tanks, which were managed by a central bureaucracy, which easily succumbed to the stresses consequent to the collapse of the central governments of the medieval kingdoms. 


\subsection{Causes for Abandonment}

The number of presently operating as well as abandoned small tanks in various provinces was given in the previous chapter. As this study proceeded, it became clear that there were different sets of reasons for the abandonment of small tanks in different parts of the dry zone. In order to identify the main reasons for abandonment, the presence of abandoned tanks was matched against dominant environmental factors such as landform, hydrology, soils and vegetation, which were easily available from maps and past studies carried out by several agencies and professionals. The comparative percentages of presently functioning and abandoned tanks in each province are given in table 3 .

As is evident from table 3, the higher percentage of abandoned tanks occur in the NP and the SP, where over 50 percent of the approximately 1,400 small tanks in each province are in an abandoned state. It should be noted that the mean annual rainfall as well as the maha season (major cultivation season) rainfall is lower in the SP and the NP than in the

Table 3. The percentages of functioning and abandoned tanks by province.

\begin{tabular}{lccc}
\hline Province & $\begin{array}{c}\text { Total number } \\
\text { of small } \\
\text { tanks }\end{array}$ & $\begin{array}{c}\text { Percentage of } \\
\text { functioning } \\
\text { tanks }\end{array}$ & $\begin{array}{c}\text { Percentage of } \\
\text { abandoned } \\
\text { tanks }\end{array}$ \\
\hline Northern (NP) & 1,424 & 43 & 57 \\
North Central (NCP) & 4,017 & 52 & 48 \\
North Western (NWP) & 6,463 & 65 & 35 \\
Southern (SP) (dry zone) & 1,410 & 46 & 54 \\
\hline
\end{tabular}

NCP and NWP. It should also be noted that because of the sodic soils that are prevalent in the SP, the small tank bunds tend to be less stable.

In the case of the NCP, out of the approximately 4,000 small tanks, around 48 percent are abandoned, while in the NWP out of the approximately 6,500 small tanks, around 35 percent are abandoned. It should be noted that the maha season rainfall in the NWP is significantly higher than in the NCP, and that there is a higher proportion of gravelly soils and rocky lands (rock knob plains) in the NCP compared to the NWP, which accounts for the higher proportion of abandoned small tanks in the NCP.

Abeysinghe (1982) states that there are several thousand abandoned tanks in the dry zone, which are kept abandoned for several reasons. He enumerates them as follows: "They lack adequate catchment area, they lack suitable agricultural soils for viable settlements, they are economically and from an engineering perspective non-viable, they lack approach roads, or are located far away from human habitation, or they are situated in forest reserves and nature reserves or wild life sanctuaries."

Abeysinghe's reasoning could be considered generally valid for explaining the abandoment of most of the present small tanks. To discover the causes for abandonment, the underlying reasons have to be analyzed. A more detailed study was made in two contrasting provinces, namely, the NCP and the SP. In this study, the occurrence of both abandoned and 
functioning small tanks as shown on the 1:63,360 scale topo maps were matched against (a) the individual tank catchment area, (b) the nature of the land forms of both the micro- and meso-catchment areas by aerial photograph interpretation and (c) the land quality in the command area of the small tank. Based on this study it could be concluded that there are different sets of reasons for the abandonment of small tanks in the different regions of the dry zone.

In respect of the NCP it was observed that in much of the western segment of this province the abandoned tanks are located in either hydrologically poorly endowed mesocatchments, or in very rocky and gravelly rock-knob-plain landforms. The early settlers had probably no proper appreciation of either the hydrology or the land quality in this region. In contrast, it was observed that in much of the eastern segment of this province there is a sharper relief of the meso land form and that this has contributed to the instability of these tanks. In times of severe cyclonic depressions, which occur during the November-December period, high intensity rainfall of around $300 \mathrm{~mm}$ per day is experienced. During such storms, the surge of overland runoff is very high on this type of landscape because of its sharp relief. This results in breaching of the bunds of tanks unless they are very robustly constructed. This is also a view supported by the locals. In contrast, in the central segment of this province there is almost a total absence of abandoned tanks, especially in the upper aspects of the sub-watersheds where the relief tends to be very subdued. Local residents also state that the small tank cascades located in the upper aspects of these sub-watersheds have been in existence and use since the medieval period.

Because of the lower regional rainfall and the higher annual evaporation in the semiarid climate of some parts of the SP, a larger catchment area is needed to capture adequate runoff to fill the tanks. This is also reflected in the lower tank density in the southeastern segment of the province. The primary reason for the preponderance of abandoned small tanks in this semi-arid environment is the occurrence of the readily dispersible sodic soils in the narrow inland valley bottoms across which these small tanks have been constructed. Tank bunds made from such soil material are unstable during the rainy period and can cause breaching of embankments and ultimately the abandonment of tanks.

\subsection{Recent History}

According to Weerawardena (1986), scripts and pillar inscriptions from 1000 A.D. support the fact that farmers had to adhere to certain laws laid down by the king or regional chieftains in relation to the repair, maintenance and management of small irrigation systems. The adherence to these laws over many generations resulted in the birth of customs and traditions, which gave the management of these irrigation systems a discipline that continued up to British times. The Rajakariya system (ancient custom of compulsory labor) of maintenance required a compulsory personal labor obligation that helped guarantee the maintenance of these small irrigation systems over a period of several centuries.

One of the important changes that affected this communal method of tank maintenance was the removal of the Rajakariya system by the British administration in 1832 on grounds that it was a form of slavery. No alternative system was introduced for the maintenance and 
repair of tanks by the community. Without any substitute for Rajakariya, maintenance was no longer enforced and many minor irrigation works fell into neglect and general decay.

From the abolition of Rajakariya in 1832 up to 1887, nobody was officially responsible for maintaining village irrigation works and this led to a degradation and decline of many minor irrigation systems, especially in the more remote parts of the dry zone. In 1887, Provincial Irrigation Boards were established, and Government Agents (GAs) were entrusted with the responsibility of executing both major and minor irrigation works in their administration areas. These Provincial Irrigation Boards were subsequently abolished in 1900 with the creation of a separate central Irrigation Department, which was held responsible for the maintenance of all irrigation schemes through the GAs. These arrangements helped only to partially arrest the 50-year period of neglect and deterioration that many thousand small irrigation systems distributed throughout the dry zone suffered.

During the nineteenth century, under British colonial administration, the restoration of some of the major ancient irrigation works was carried out. Alongside this some attention was also given to the rehabilitation and improvement of indigenous small village tank irrigation systems. These activities were mainly promoted by the need for producing adequate staple food within the country in order to avoid the heavy expenditure incurred on food imports. A revival in the repair, rehabilitation and improvement of the numerous small village tank irrigation systems was introduced immediately after World War I. This gave a significant impetus to the improvement and stabilization of the small tank irrigated agriculture, especially in the NCP and NWP.

Following independence in 1948, the responsibility for maintaining minor irrigation schemes was taken over by the Ministry of Agriculture, and with the introduction of the Paddy Lands Act of 1958, the DAS was entrusted with the responsibility for maintaining all village irrigation schemes in addition to investigation and construction as well as the maintenance of minor village tanks. The efforts of the DAS were, however, mainly diverted to the implementation of the Paddy Lands Act, and less to maintenance of minor village works.

With the Agricultural Productivity Law No. 2 of 1972, responsibility for executing all minor irrigation works was handed over to the Territorial Civil Engineering Organization (TCEO) that was considered to be a decentralized system with a high degree of engineering orientation. The TCEO was in operation for little over 5 years and neither this organization nor the minor irrigation works could adjust comfortably to benefit each other. With the dismantling of the TCEO, the minor works were transferred to the Irrigation Department in 1979 and in the same year they were retransferred to the DAS.

The Agrarian Services Act No. 59 of 1979 revived the DAS, and once again the maintenance of minor irrigation works was vested with the DAS, because the maintenance of minor irrigation works was neglected by the Irrigation Department due to its preoccupation with major irrigation schemes.

The Agrarian Services Act No. 59 of 1979 empowered the DAS with the maintenance of all minor irrigation works with a command area of up to 80 ha and it also ensured provisions for water administration and management, which covered the following main functions: 

a. Holding of Kanna meetings (pre-seasonal meetings of farmers) on time.
b. Efficient maintenance of irrigation systems.
c. Enforcement of such established customs affecting wastage and proper timing of agricultural operations.
d. Proper timing of paddy cultivation.
e. Joint measures for conservation of soil.

As discussed by Roberts (1980) the abolition of the Rajakariya system in 1832 caused a serious disruption in the management and maintenance of minor irrigation works. The abolition of the Velvidane (traditional irrigation headman) system under the Paddy Lands Act of 1958 also resulted in the degradation of the leadership, discipline and maintenance of minor irrigation schemes. The Velvidane was an elder farmer, elected democratically and paid in return for his services in water issues, regulations, control and management. The Paddy Lands Act of 1958 eliminated the traditional institution of the Velvidane and substituted in its place the "Cultivation Committee" or CC. The CC was set up mainly to implement the provisions of the Paddy Lands Act and, in particular, the treasury regulations of this act. The CC had to face many problems, both legal and otherwise. This resulted in a further breakdown in the rural irrigation sector. These aspects will be discussed further in chapter 5 .

While the preceding section briefly sketches out the supporting management and maintenance practices that existed and were modified by different administrations over the past 160 years, it should also be noted that many beneficial traditions and alternative practices built up over the centuries were the mainstay in the upkeep, maintenance and operation of these minor irrigation systems. 


\section{CHAPTER 3}

\section{Rationale for Selection of Five Representative Small Tank Cascade Systems: Their Main Characteristics, Present Status and Uses}

\subsection{Rationale for Selection of Five Representative Cascade Systems}

As observed in the two previous chapters, a high density of small tank systems is mainly encountered in the central portion of the NWP and in the central portion of the NCP. A careful examination of figures 1 and 2 reveals that in the SP, the higher density of small tanks is found in the transitional region from the dry to the semi-arid environment.

It was also noted earlier that the southern aspects of the NWP experience a somewhat higher rainfall and also have the highest density of small tanks, and that the semi-arid regions of the SP have a distinctly lower rainfall and also have the lowest density of small tanks. At the same time, the amount and distribution of rainfall for most of the NCP are fairly representative of the rest of the dry zone. It should also be kept in mind that within the time scale of this study, it would not have been possible to conduct field studies at more than 5 locations, each representative of a distinctive rainfall-climatic and surface-hydrological regime. These rainfall-hydrological regimes have been mapped and characterized in several studies and publications by Hunting Survey Corporation (1963), Panabokke and Kannangara (1975), Kannangara (1984), Somasiri (1992), IWMI Study Team (1996).

In a recent study conducted at the request of the mahaweli Authority of Sri Lanka (MASL), the hydrography of the small tank cascade systems that make up the NCP and part of the NWP was demarcated and a master map of 1:250,000 scale was published by Panabokke (1999).

A demarcation of rainfall probability regime zones for the dry and intermediate zones at a scale of 1:500,000 was developed by Kannangara (1984). This has been further improved by the Land and Water Use Division of the Department of Agriculture.

By superimposing the rainfall probability regime zone maps over the cascade master maps, the modal cascade situation in respect of each of the three provinces was identified. The location of each of these identified modal cascades in respect of each of the three provinces is shown in figure 5, together with the dominant agro-ecological demarcation according to the most recent agro-ecological demarcation of the island.

In the NCP, which straddles a single agro-ecological region of DL1 (depicted in figure 6), the northern location of Pihimbiyagollawa cascade (cascade 1), as seen in figure 5 , is representative of the typical high density small tank cascade distribution pattern prevalent in the upper Kanadara Oya basin (all cascade locations are marked in figure 5). 
Figure 5. Locations of the five selected modal cascades.

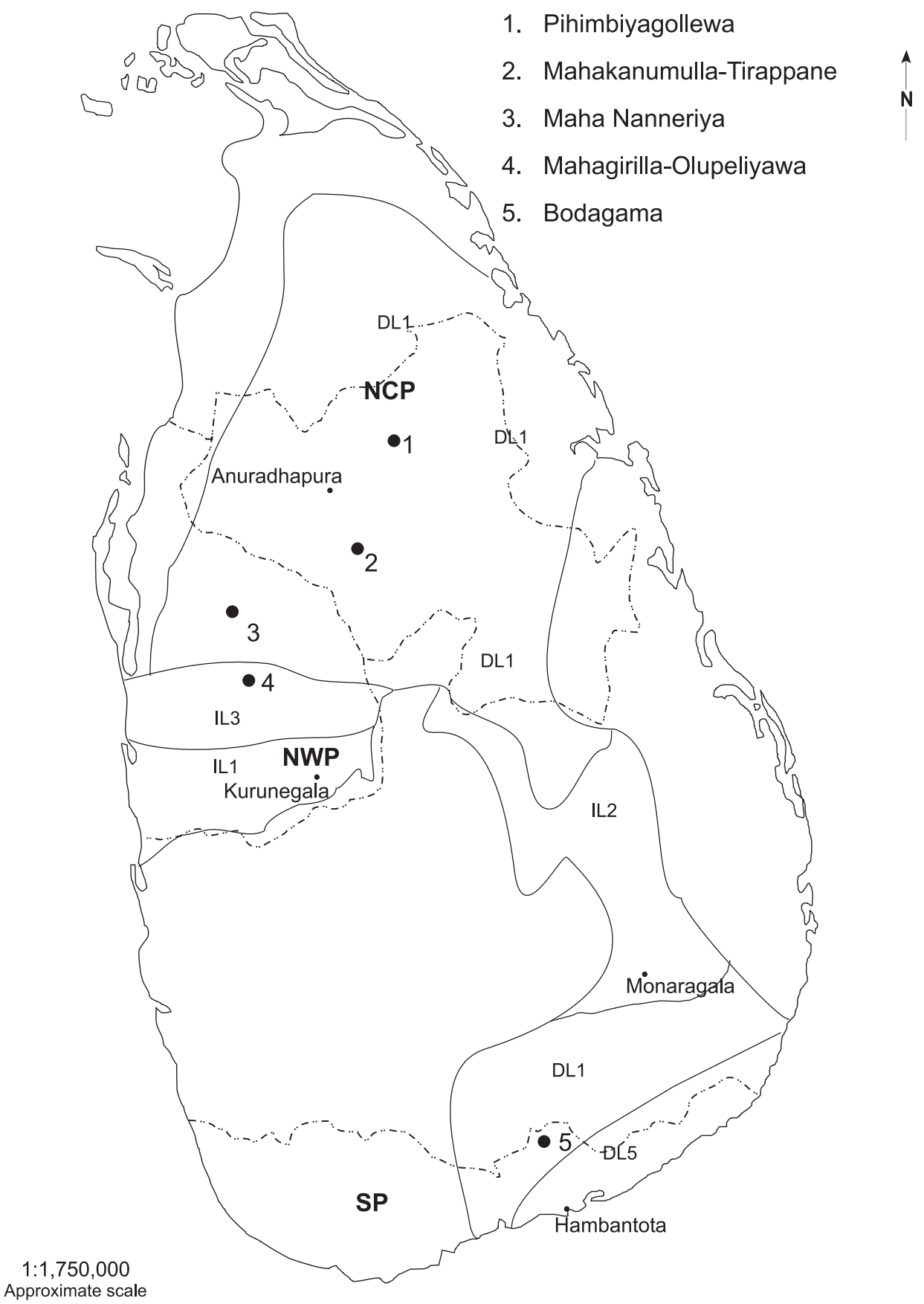


The next cascade, Mahakanumulla (cascade 2), includes the two adjacent cascades of Mahakanumulla and Thirappane, which are typical of the medium density small tank cascade distribution pattern prevalent in the mid-Malwathu Oya basin. The Mahakanumulla cascade has also been the field research site for the nearby maha Illuppallama Research Station, while the Thirappane cascade has been the IWMI study location since 1990 by Itakura and Abernethy, later by Shinogi and Vitarana (unpublished). A considerable body of field research data has been already gathered in these two cascade locations, which was considered an added advantage.

In respect of the NWP, it is evident from figures1, 2 and 6 that this province is made up of a dry (DL1) rainfall region in the northern segment, and an intermediate (IL3) rainfall region in the southern segment. Accordingly, the maha Nanneriya cascade (cascade 3) was identified and selected for the dry zone segment of this province that is located within the Nanneri Oya sub-watershed, which is within the main Mi Oya basin. Correspondingly, the two adjacent cascades of maha Girilla and Olupeliyawa (cascade 4) were identified and selected for the intermediate zone (IL3) segment of this province and it is located within the Kuda Oya sub-watershed within the main Deduru Oya basin.

In respect of the SP, it should be noted that in the area shown in figure 5, which has a high tank density of 400-800 tanks per topo sheet, more than 80 percent of the small tanks are in an abandoned state- a few have been restored over the last 35 years. On the other hand, the greater proportion of the presently functioning small tanks are found in the transitional zone from the dry zone DL1 to the arid zone DL5 (figure 6). Accordingly, the two adjacent cascades of Bodagama and Ranmudu Ara, both of which are located on the main tributary of the Malala Oya basin, which also falls within the transitional agro-ecological region from DL1 to DL5, were therefore identified and selected as cascade 5 (figure 5).

\subsection{Main Characteristics of the Five Selected Modal Cascades}

The main characteristics of each of the cascades is given in table 4 and more detailed data is given in annex 1. Figures 7, 8, 9, 10 and 11 show the main features of these five selected cascades, including the component tanks and command areas.

From table 4 it can be seen that the first 3 cascades fall within a specific category where the ratio of cascade area to water spread area is between 8 and 11, and where the ratio of total tank capacity (in acre feet) to total command area (in acres) is between 2 and 3, and the tank density is around one tank per 142 ha. All three cascades are therefore located within a similar hydro-geomorphological region.

Cascade 4, which is located in an area with a higher rainfall regime, has a higher tank density of 1 tank per 40.5 ha, and a lower ratio of cascade area to water spread area as compared with the first three cascades. Also, the ratio of total tank capacity (in acre feet) to total command area (in acres) in cascade number 4 is around 1.7. All this is in conformity with the higher rainfall experienced in this intermediate agro-ecological regime of IL3.

In the case of cascade 5, which is situated closer to the agro-ecological regime of DL5, which is a very dry environment, out of a total of 19 small tanks only 9 are presently functioning tanks, while one is undergoing reconstruction, and the other 9 are abandoned. This is a common feature of all cascades located in this environment in the southeastern dry 
Figure 6. Agro-ecological regions of the dry and intermediate zones.

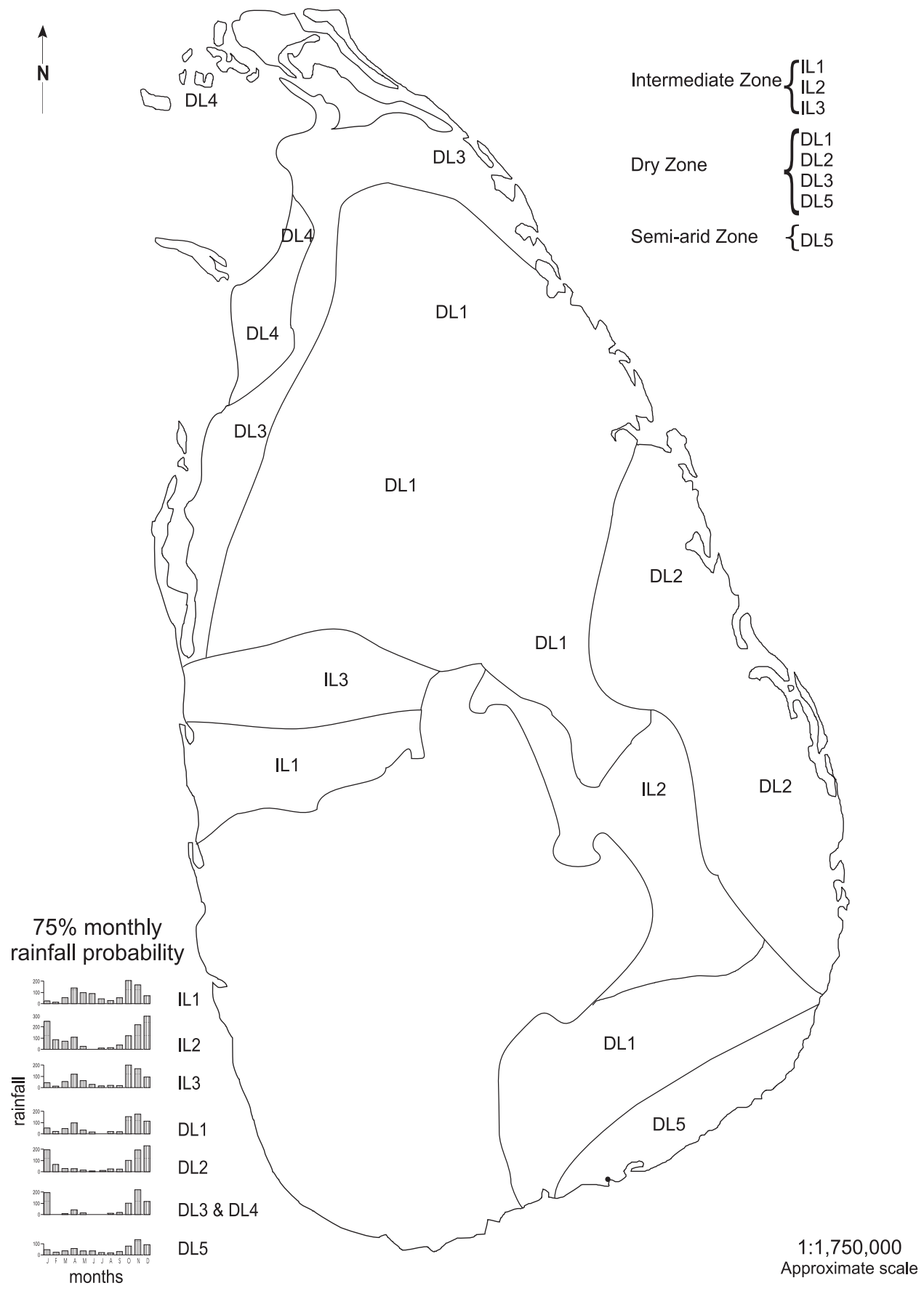


Table 4. Main characteristics of the selected cascades.

\begin{tabular}{lcccccccc}
\hline Cascade * & $\begin{array}{c}\text { Approximate } \\
\text { cascade area }\end{array}$ & $\begin{array}{c}\text { Total water } \\
\text { spread area } \\
\text { (WSA) }\end{array}$ & $\begin{array}{c}\text { Ratio: } \\
\text { cascade/ } \\
\text { area WSA }\end{array}$ & Total tank capacity & $\begin{array}{c}\text { Total } \\
\text { command } \\
\text { area }\end{array}$ & $\begin{array}{c}\text { Number of } \\
\text { small tanks } \\
\text { within main } \\
\text { cascade }\end{array}$ \\
& (ha) & (ha) & & $\mathrm{m}^{3}$ & Acre feet & (ha) & (acres) \\
\hline 1. Pihimbiyagollawa & 3,403 & 426 & 8.0 & $4,350,490$ & 3,527 & 677 & 1,672 & 23 \\
2. Maha Kanamulla & 3,885 & 471 & 8.2 & $5,279,302$ & 4,280 & 595 & 1,470 & 25 \\
Thirappane & 2,120 & 192 & 11.0 & $1,988,373$ & 1,612 & 193 & 476 & 9 \\
3. Maha Nanneriya & 5,283 & 460 & 11.5 & $5,671,549$ & 4,598 & 613 & 1,514 & 41 \\
4. Maha Girilla & 2,023 & 258 & 7.8 & $2,153,659$ & 1,746 & 425 & 1,051 & 47 \\
Olupeliyawa & 583 & 132 & 4.4 & 916,477 & 746 & 177 & 437 & 21 \\
5. Bodagama & 1,679 & 311 & 5.4 & $5,617,276$ & 4,553 & 366 & 906 & 19 \\
\hline
\end{tabular}

* Hereafter these will be referred to by number.

zone of the country. This also contrasts with the rest of the cascades situated in the dry and intermediate zones DL1 and IL3 where there are no abandoned tanks within the cascade.

The ratio of total tank capacity (in acre feet) to the command area (in acres) is between 2 and 3 for the first 3 cascades, which is typical for this environment. In the case of the fourth cascade, because of the high rainfall this ratio is between 1.6 and 1.7. In the case of cascade 5, which is located in a much drier environment, the more significant difference from the previous 4 cascades is that the ratio of the total tank capacity (in acre feet) to the total command area (in acres) is between 4.5 and 5.0, which is a necessity for such a dry environment.

The size-class distribution of the tanks that make up each cascade is given in table 5 . In the case of the first 3 cascades, a greater proportion of all tanks that have a water spread of more than 10 ha fall within the size-class of 20-40 ha water spread area. At the same time, in the case of cascade 3, a very high proportion, i.e., more than 60 percent of the tanks fall within the size-class of less than 10 ha water spread. It should be also noted here that not all of these very small sized tanks are used for paddy cultivation, especially those with a water spread of less than 4 ha are used more as storage ponds for multiple uses.

Table 5. Size-class distribution of tanks within each cascade.

\begin{tabular}{lccccr}
\hline Cascade & \multicolumn{5}{c}{ Size-class distribution } \\
\cline { 2 - 6 } & \multicolumn{5}{c}{ Water spread area (ha) } \\
\cline { 2 - 6 } & $>80$ & $40-80$ & $20-40$ & $10-20$ & $<10$ \\
\cline { 2 - 6 } 1. Pihimbiyagollawa & 1 & 2 & 5 & 2 & 13 \\
2. Maha Kanamulla & - & 3 & 10 & 4 & 4 \\
Thirappane & 1 & 2 & 1 & 2 & 4 \\
3. Maha Nanneriya & - & 1 & 6 & 4 & 29 \\
4. Maha Girilla & - & - & 5 & 4 & 38 \\
Olupeliyawa & 1 & - & 2 & 2 & 17 \\
5. Bodagama & 1 & - & 1 & 7 \\
\hline
\end{tabular}


In the case of cascade 4, approximately 80 percent of the total number of tanks fall within the size-class of less than 10 ha of water spread. This is a characteristic feature of the high density small tank distribution pattern for this part of the intermediate zone

The size-class distribution for cascade 5 follows the typical pattern for this semiarid region, with about 25 percent being large sized tanks and about 75 percent of tanks being of size-class less than 10 ha.

\subsection{Present Status and Uses}

\section{Pihimbiyagollawa-Cascade 1}

Of the total of 23 tanks present within this cascade (figure 7), 18 are in either fairly good or good condition. These have been rehabilitated at least once since 1970, with 15 of them having been rehabilitated after 1991. There are no badly deteriorated tanks in this cascade, except for 5 tanks that are in a moderate state of repair. These are very small tanks that have either never been rehabilitated or have been rehabilitated once in the early 1970s.

The smaller tanks have a sluice each for the right bank and the left bank, usually of the junction block type. The larger tanks, which have been recently rehabilitated, have three sluices with an additional central sluice usually of the tower type made up of a concrete cylindrical tower together with an iron shaft and sluice door. The spillways are in good condition in 16 of the tanks and are in a dilapidated condition in 6. The spillway is damaged in the largest tank, the Pihimbiyagollawa tank. A rudimentary conveyance canal system is used for the smaller tanks and a more formal layout is used for the larger tanks.

The tank beds of 15 of the 23 tanks are substantially silted, while the remaining 8 are moderately silted. Water lily and lotus cover most of the larger tanks. There is no evidence yet of agrochemical pollution.

The total extent of Puranawela (old paddy fields) is 194 ha and Akkarawela (new leasehold paddy fields) is 482 ha. A total of 1,011 families live within this cascade of tanks of which 812 are paddy land holding families. The main land use is for paddy cultivation, mainly during the maha season, and if irrigation supply is left over in seasons of high rainfall, a Bethma (agreed rules for sharing water in scarce situations) yala season (minor cultivation season) crop is also cultivated. The mean cropping intensity for the maha season over the last 10 year period is around 70-80 percent for the bigger tanks and around 40-50 percent for the smaller tanks. Tank water is also used for bathing, washing clothes, animal (mainly buffalo) wallowing and some brick making. There is no fish rearing, although the natural fish stock is harvested when needed.

Because of ready access to rainfed chena land, there is little or no cultivation of other food crops (OFCs) on the irrigable land during the dry yala season.

Agrowell development is in the very initial stages, with only 3 agrowells located around the command area, and 19 in the upland area. Seventy-five percent of these wells were constructed with government assistance under the Janasaviya fund (government welfare program for poverty alleviation). Because of the exceptionally high rainfall received in this area during the 1998 yala season, there was not much ${ }^{\text {OFCS }}$ cultivation under these agrowells. 

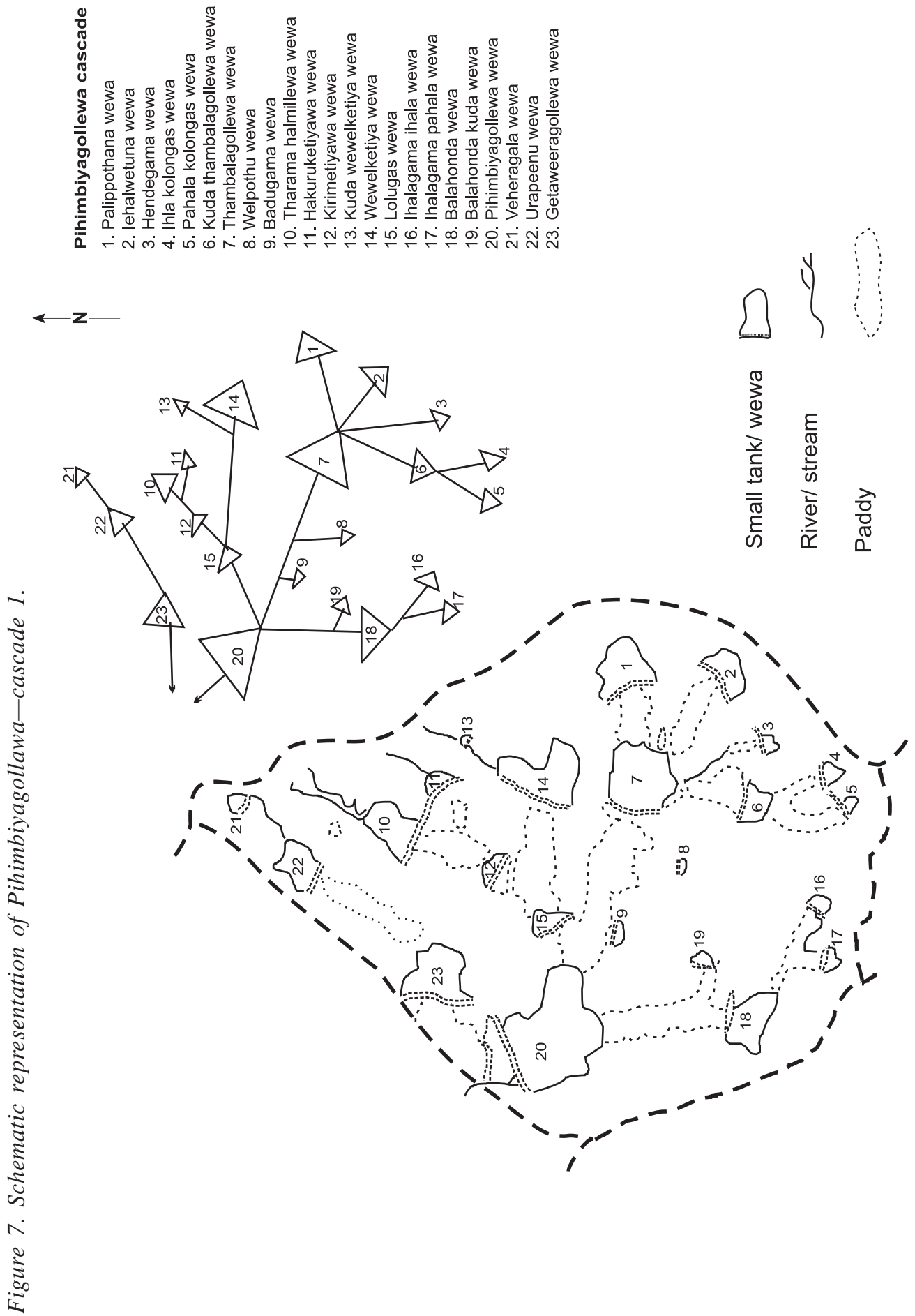
As we understood, farmers are yet in the very early stages of agrowell cultivation within this cascade area.

\section{Mahakanumulla, Thirappane-Cascade 2}

As mentioned earlier these are two adjacent cascades (figure 8). Mahakanumulla is the branched type with a form index (ratio of length to width) of 2.8, while Thirappane is the linear type with a form index of 1.2. Of the 27 tanks within the Mahakanumulla cascade, 5 are located along the main valley and the rest are located along the side or branch valleys. Eighteen tanks have received some form of rehabilitation over the last 15 years and are therefore in good condition. There are two medium-sized tanks with deteriorated bunds. In the Thirappane cascade, 4 out of the 9 tanks are located along the main valley, and 8 of the tanks except the main Thirappane tank have received some form of rehabilitation since 1981 and are therefore in good working condition.

The sluices of the smaller tanks are of the junction block type, while 3 of the bigger tanks have the tower type. In the Mahakanumulla cascade, 11 of the tanks have malfunctioning sluices, while in the Thirappane tanks there is only one malfunctioning sluice. The spillways are in good condition in all the tanks and an improved conveyance channel system is usedmainly under the larger tanks.

The tank beds of 15 of the 27 tanks of Mahakanumulla cascade are heavily silted, while the tank beds of 10 are moderately silted. Six of the 9 tanks of the Thirappane cascade have tank beds that are heavily silted. Lotus growth is present in almost all the tanks, while salvinia was observed in the Mahakanumulla and Meegassagama tanks. There is no evidence of agrochemical pollution yet observed in any tank, but the immediate catchment of the Thirappane tank is used as a dumping ground for garbage from a nearby town bazaar and could cause a pollution threat in the long run.

The total extent of the Puranawela is approximately 324 ha at Mahakanumulla, and 283 ha at Thirappane. A total of around 1,600 families live within the first cascade and 350 within the second cascade. The main land use in both cascades is for paddy cultivation during the maha season, and to a limited extent in the yala, according to the availability of irrigation supply. The cropping intensity for the maha season for the last 10 -year period is 70-80 percent for the bigger tanks, and 30-40 percent for the smaller tanks. For the Mahakanumulla cascade and for the Thirappane cascade it is 50-60 percent for the bigger tanks, and 25-30 percent for the smaller tanks.

The tank water is used for multiple purposes, including bathing, washing, animal wallowing and, to a little extent brick making. Traditionally, fishing is done after the yala harvest on a predetermined date. Following a formal announcement fishing is done within specific hours during the day. Fingerlings and small fish are returned to the tank and the produce is shared after the harvest has been gathered.

Cultivation of OFCs during the dry yala season under gravity irrigation was introduced in the Walagambahu tank located within the Mahakanumulla cascade in the late 1970s. When prices for these OFCs were good there was rapid expansion, but it has declined after prices went down. 


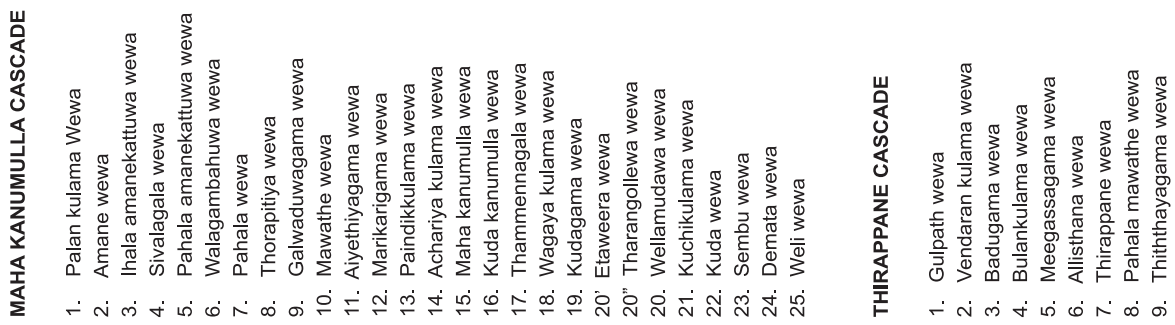

$\longleftarrow \mathbf{z}$

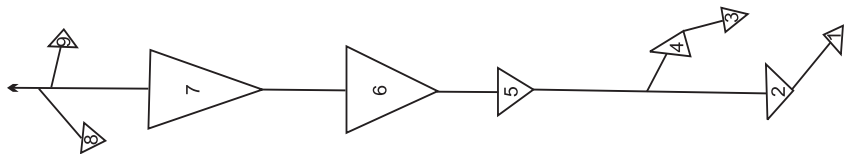

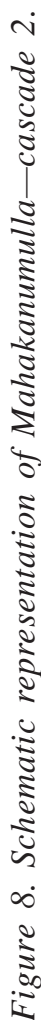
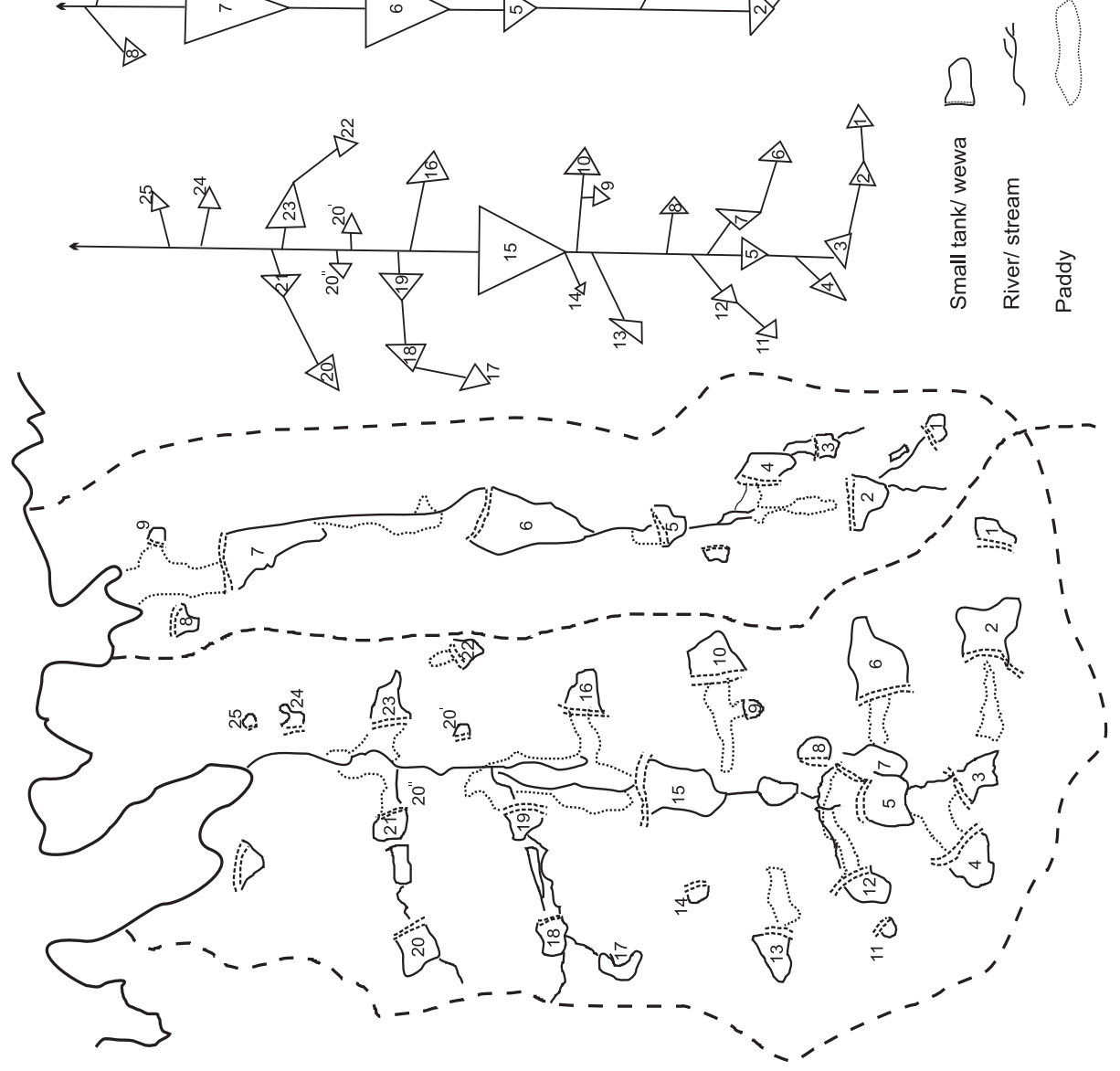
Agrowell development took place very rapidly in the Mahakanumulla cascade from the 1990s. Presently there are 120 agrowells in the command area, and 57 in the highland area.

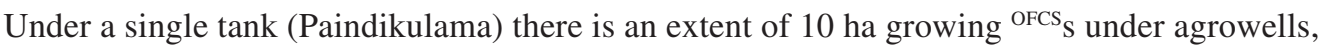
and 06 ha under the adjacent Marikkaragama tank during the yala season. A total extent of 53 ha of OFCS cultivation under agrowells has taken place for the whole cascade.

\section{Maha Nanneriya-Cascade 3}

Of the total of 41 tanks present within this cascade (figure 9), 35 tanks are in fairly good to good condition and 6 tanks are in a moderately deteriorated state. A total of 25 out of these 35 tanks have had some rehabilitation carried out on them over the last 20 years, of which 20 have been rehabilitated during the last 10 years. There were no badly deteriorated tanks or damaged bunds or spillways observed within this cascade.

Apart from the main axis of this cascade, along which the main maha Nanneriya tank with a waterspread of 121 ha is located, in the lower reaches there are 5 other side valleys of varying size along which a several number of tanks are located. All tanks located along the main axis and the larger side valleys are in very good condition. It is mainly the very small tanks with waterspread areas of less than 4 ha that are not in very good condition. The larger tanks have two sluices, one for each bank, the smaller tanks have only one sluice. The sluices are both of the tower type and the junction block type and both types are in good condition.

Compared with the two previous cascades, the degree of siltation is significantly lower in the tanks located within this cascade. The tank beds are heavily silted only in the medium sized tanks. Most of the very small tanks are only moderately silted. Only 25 percent of the tanks are affected by lotus growth. The deeper tanks such as the maha Nanneriya tank are not significantly affected by weeds, while the shallower tanks are affected. There is evidence of initial stages of pollution, mainly from the residue of a large number of illicit liquor distillation units that operate in the area.

The total extent of Puranawela is approximately 310 ha and Akkarawela 301 ha. A total of 1,912 farmer families live within this cascade. The main land use is for paddy cultivation during the maha season and very little paddy during the yala season expect for small cultivations under a very few of the bigger tanks. The amount of rainfall received during the yala season in this region is significantly less than in the areas of the two previous cascades. The cropping intensity for the maha season for a 10 year period is around 100 percent for the larger tanks, around 60-70 percent for the medium sized tanks, and around 30-40 percent for the smaller sized tanks. The cropping intensity for the yala season is not significant for this cascade because it is generally very dry.

In this cascade the major use of water is for paddy cultivation and domestic use for bathing and washing. Unlike in the previous cascade there is no systematic fishing schedule. Though it is reported that there was a tradition of fishing following the main harvest, it is now practiced according to individual wishes without any control and regulation.

Compared to the previous cascade, very little agrowell development has taken place within this cascade. Only two agrowells were found. Correspondingly there has been no 


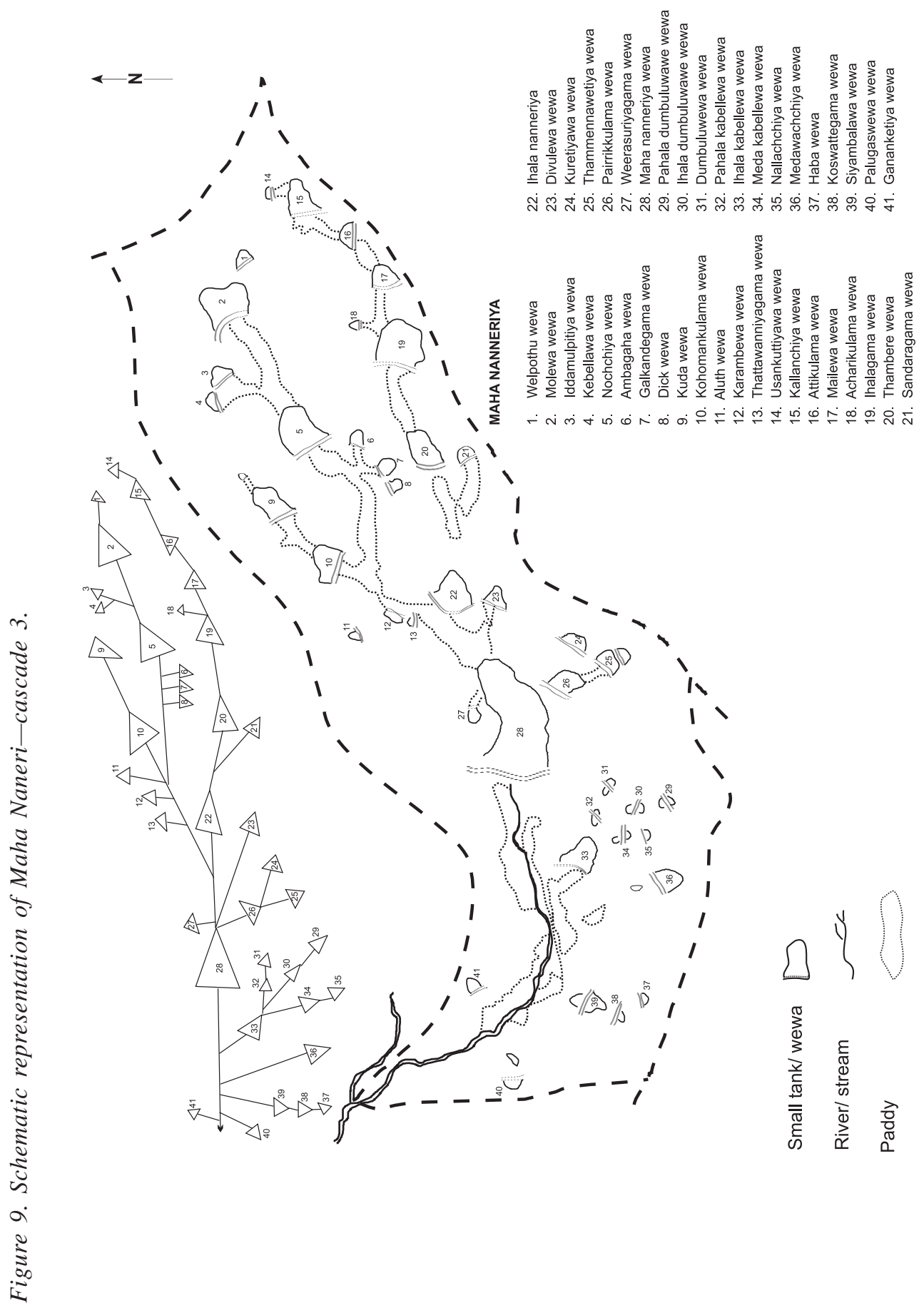


development of OFCs cultivation in the recent past in this area, and the reasons for this were not very clear.

\section{Maha Girilla-Olupeliyawa-Cascade 4}

As mentioned earlier there are two adjacent cascades here (figure 10). The maha Girilla is the larger cascade of approximately 2,023 ha acres in extent and Olupeliyawa, the smaller cascade, of approximately 583 ha in extent. The former has a total of 47 tanks of which five have a waterspread of 20-40 ha size and which are located across the main valley or across the larger side valleys. A total of 38 tanks, or 80 percent, fall within the size-class of less than 10 ha water-spread area, and out of this a total of 25 tanks fall within size-class of less than 4 ha water-spread area. Thus, around 50 percent of these small tanks would fall within the category of very small or micro-tanks which have a water spread of less than 4 ha. This is a characteristic feature of the size distribution pattern of small tanks in this agro-ecological environment.

In the case of the Olupeliyawa cascade, 17 out of 21 tanks have a waterspread area of less than 10 ha, and out of these 17, a total of 11 have a waterspread area of less than 4 ha, which again is characteristic of this environment.

The general condition of the bunds of the smaller sized tanks is very poor. Rehabilitation work in the recent past has been carried out mainly on the larger sized tanks and little or no work on the very small tanks. The 7 larger sized tanks of the 20-40 ha waterspread size-class have had rehabilitation work done at least on two occasions between the 1970s and the 1990s. In the 6 medium sized tanks of the 10-20 ha size-class, rehabilitation has been done only once during the past 15 years. The rehabilitated tanks in general have sluices in good working condition while the smaller tanks, which have had no rehabilitation, have sluices of poor condition.

Siltation of the tank bed is common in tanks of all sizes in both cascades. Severe siltation is quite visible in the smaller tanks located at the head end of the main and side valleys and less evident in the tanks located in the lower aspects of the valleys. Almost all important tanks in both cascades are covered with lotus, while some smaller tanks have a preponderance of tall grass weeds along their fringes. Salvinia is also present to a significant extent, especially in those tanks that do not dry out adequately during the dry season. Complaints of deteriorating water quality are being received, mainly from the uppermost tanks, which act as sinks for agrochemicals and other pollutants. People complain of scratching, or skin irritation after bathing in these tanks-which indicates, to some extent, the degree of chemical pollution.

The total extent of Puranawela is 309 ha in the maha Girilla cascade and 132 ha in the Olupeliyawa cascade. In this area, however, the proportion of Akkarawela is very low compared to the previous cascades, which indicates less expansion of paddy land in recent times. The main land use is for paddy cultivation during the maha season, and around 30 percent in the yala season, irrigated by the larger tanks. The cropping intensity for the maha season is around 100 percent for the larger tanks, especially the hydrologically better endowed tanks located along the main valleys, and for the side valley tanks it is between 50 

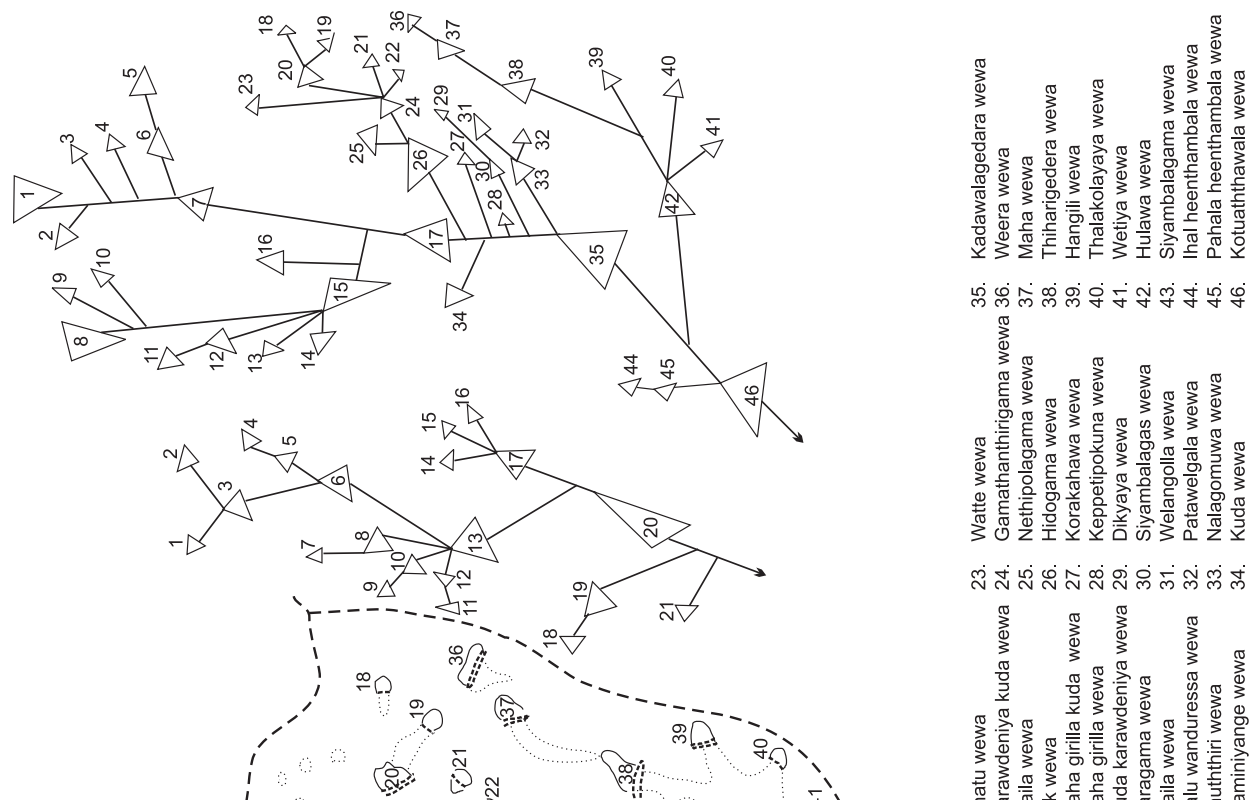

மூ

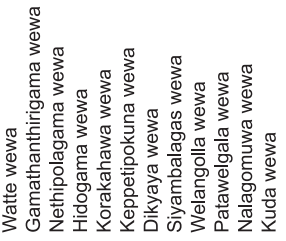

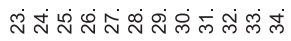

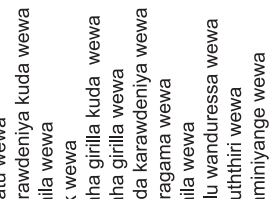

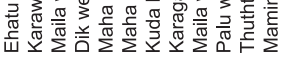

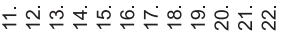

1
0
0
0
0
$\vdots$
$\vdots$
$\vdots$
0
0
0
0
0
0
0

$\frac{\sqrt{2}}{2}$
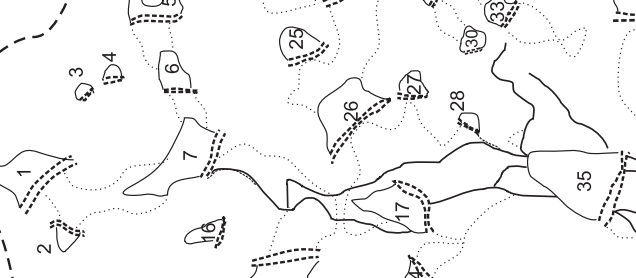

(2)
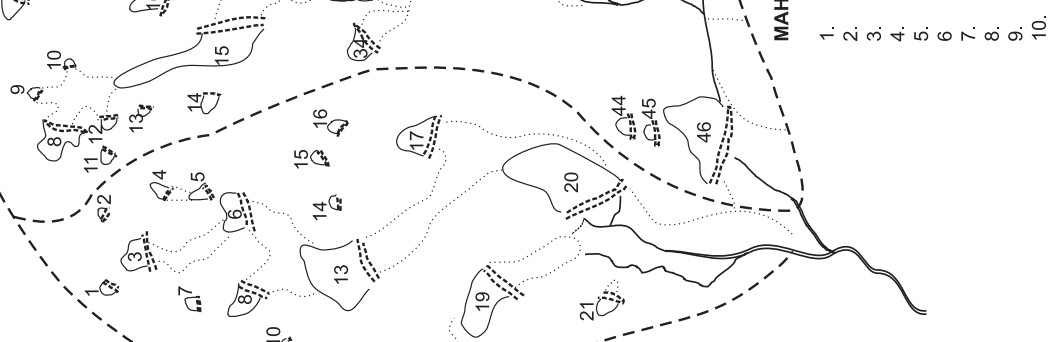

다

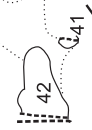

六

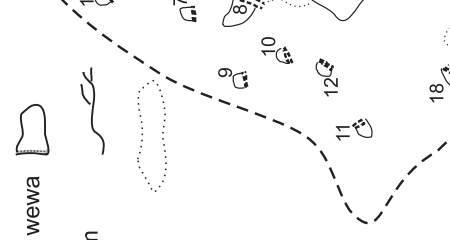

$\infty$

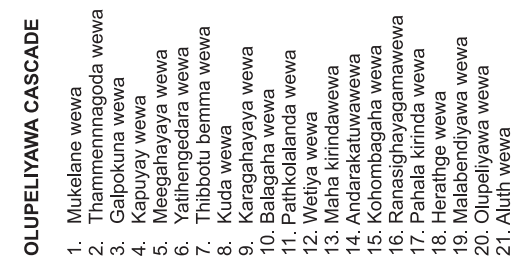

$\stackrel{-}{0}$

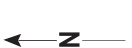

离

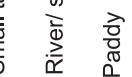

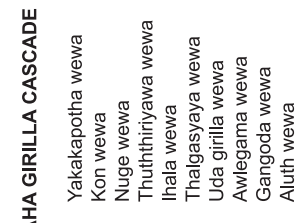


percent to 80 percent. A special feature in this environment is the combination of both rainfed and irrigated paddy cultivation. Because of the early commencement of seasonal rains and the sandy texture of the soils, land preparation commences during mid-September and the rice is rainfed during the initial 4 to 6 weeks after which it is supplemented with irrigation issues. The amount of rainfall and its distribution throughout the season is such that only few supplementary irrigation issues are necessary. After 1995 several of the tanks located higher up on the cascade have taken to the cultivation of OFCS during the yala season.

No proper fishing is carried out in these tanks. Individuals indulge in rod and line fishing whenever they need some fish supplement in their diet. It is also reported that with increasing aquatic plants, the fish population is diminishing.

Only a very few agrowells have been developed within these 10 cascades, and even these are not fully utilized. It must be noted here that the main upland areas consist of coconut plantations because the rainfall in this environment is adequate to meet the annual evapotranspiration requirements of the coconut palm. Hence, there is no great incentive for agrowell development. Also, in this agro-ecological region of IL3, there is very little chena cultivation in the upland which is occupied mostly by perennial tree crops, mainly coconut that gives a modest but stable economic return throughout the year.

\section{Bodagama-Cascade 5}

Although figure 11 shows the two cascades of Bodagama and the adjacent Ranmudu Ara, only the former cascade was studied in detail because the latter had only 2 operational tanks and 9 abandoned tanks. In the Bodagama cascade, of the 19 tanks shown in figure 11 only 9 tanks are operational, while 9 are in an abandoned state, and one is under restoration.

The maha Aluthgam Ara Wewa, which was restored in the 1980s, is the largest tank with a waterspread of close to 202 ha, and located at the lowest end of the main valley. The Bodagama tank with a waterspread of 14.5 ha is the oldest settled tank, which has also been rehabilitated on four occasions since 1938. There is strong evidence that this tank settlement had been in existence before 1817. This tank is located in the upper aspect of the main valley, and there are 5 abandoned very small micro tanks above this tank. There is no evidence of these abandoned tanks having been settled, even in the distant past. The tank of next importance is the Angunakola maha Wewa which is situated midway along the main valley and has a waterspread of 73 ha. This tank was restored and settled around 1960. The other 6 tanks which have waterspread areas of less than 4 ha had been earlier in an abandoned state and were restored at various times from 1939 onwards.

The bunds, sluices and spillways of the presently functioning 9 tanks are in good condition, mainly because the Norwegian Agency for Development Cooperation (NORAD) funded Integrated Rural Development Project (IRDP) of the Hambantota district has been making regular investments on the rehabilitation of these tanks over the last 15 years. There is no evidence of serious siltation in all these tanks, nor do they carry a high density of aquatic weeds and lotus. Pollution in tanks was also not apparent, perhaps on account of the low intensity of human settlement and pollution related activities.

The traditional Puranawela lands are present only in the older, settled Bodagama tank where 14.6 ha out of its 20.6 ha of command area is under Puranawela holding, and the 
Figure 11. Schematic representation of Bodagama-cascade 5.
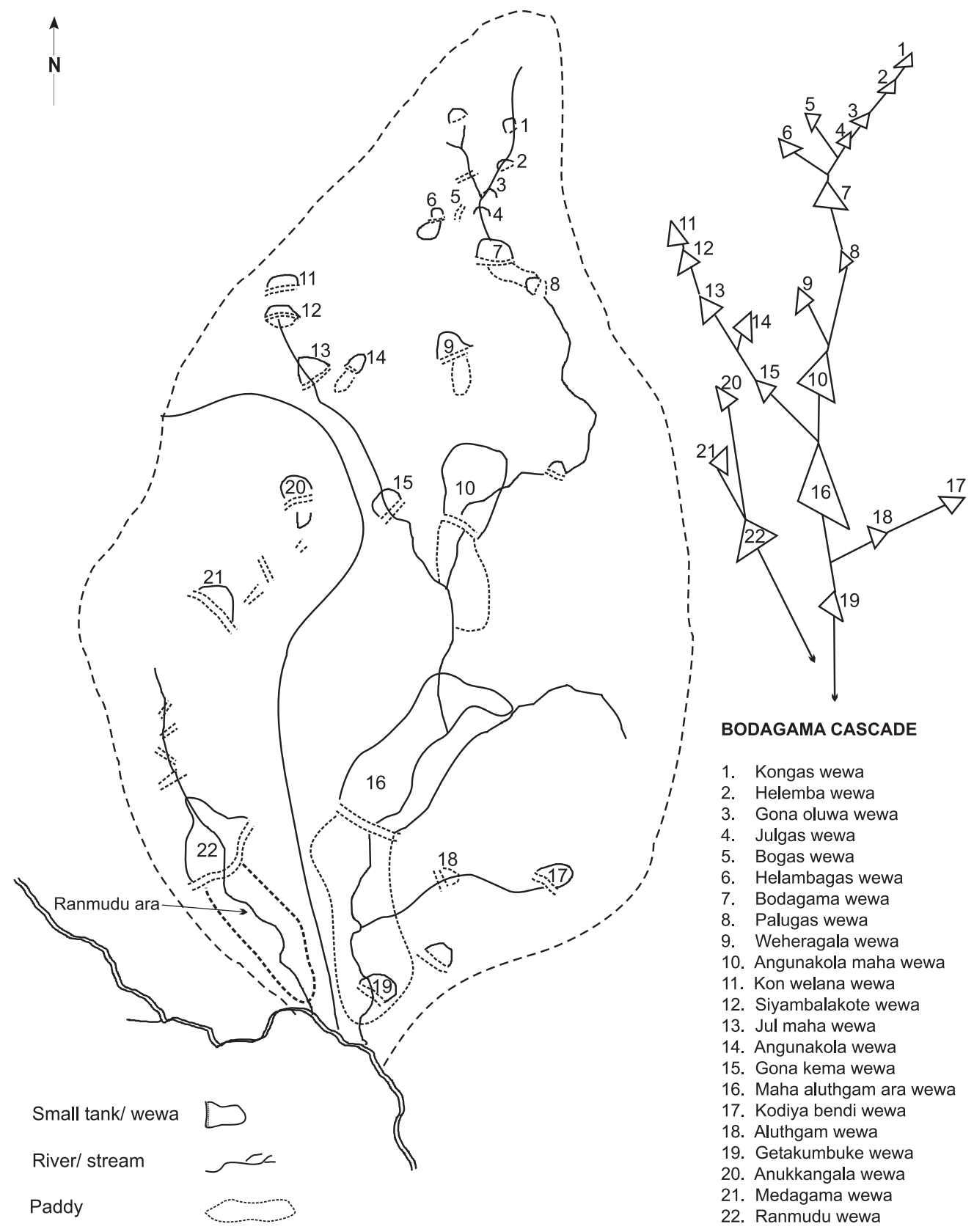
Veheragala tank where 5.6 ha out of its 16 ha is under Puranawela holding. A total of 810 families live within this cascade of 9 tanks with a total command area of 366 ha, of which 650 families are land holders.

The main land use in the lowland is for paddy cultivation, which is mainly confined to the maha season. This is in addition to chena cultivation, which is the main activity in this area. The normal cropping intensity for the maha season is between 50 to 70 percent, although it has been 90 percent over the recent past 3 years because of very good seasonal rainfall. Tank water is used for bathing, animals needs and some brick making. There is no fish rearing at present, though initial plans are under way for establishing organizations for fish rearing in the larger tanks.

Because chena cultivation is the main activity in this area, there is no real inducement for the cultivation of OFCS crops under irrigation or agrowell conditions. Each farm family cultivates 1.2-2.02 ha of chena land in the maha season within the cascade area itself. 


\section{CHAPTER 4}

\section{Design of Tank Cascade Systems: Hydro System, Maintenance and Tank Use}

\subsection{Design of Tank Cascade Systems}

As can be seen in figures 7-11, tanks of varying sizes and capacities are located along the main valley of the meso-catchment basins, and also along the side valleys which have a good catchment area. There are no recorded scripts or historical documents relating to the methods employed in site selection and the location of small tanks along these inland valleys during the ancient or medieval periods. At best, some fragments of oral tradition handed down from past generations are still available with some of the village elders now living within these cascades.

According to this oral tradition, the initial settlements usually took place in the middle segment of the main valley. The settlement started with a smaller tank which was progressively increased in size by successive generations. Evidence of this was seen in some recently excavated cross sections of bunds of some old small tanks that were being rehabilitated by the DAS - particularly where a whole cross section was exposed for placing new concrete tower sluices in position. One could clearly observe, in these cross sections, different layers of differently colored soil material of varying thickness that had been placed in position at different periods, which could not however be adequately dated to identify their age.

According to tradition, in selecting the most appropriate location within the main valley, a site that had a low, rounded rock outcrop that could have been used as a natural spillway essentially determined the location of the main tank bund. This had to be at the terminal end of either the left or right bank extremity of the main tank bund. In all of the small tanks which had a waterspread size area of more than 20 ha, the spillways were located at these natural low relief rock outcrops. In studying the detailed geomorphology of this peneplained land surface, it is not surprising to find a high incidence of such rock outcrops of varying shapes, form and relief. The more common Rock Knob-Plains (RKPs) and Erosional Remnants (ERs) commonly found on the 1:60,000 scale soils and landform maps, quite strikingly indicate their pattern and intensity of occurrence across this landscape.

The next stage in the settlements within the cascade was the application of the knowledge and experience gained from this middle location tank to the lowest end of the main valley, where a larger size tank was possible. All the lower-end tanks, that were studied, had ideally suited spillway sites situated on low rock outcrops, some of which had been slightly chiseled and lowered in elevation. 
The subsequent tanks within a cascade were constructed in the upper part of the main valley and across some of the bigger side valleys, as in the case of the Mahakanumulla cascade (cascade 2). Availability of a suitable spillway site appears to have been the primary consideration in the siting and location of all subsequent small tanks within the cascade.

While the foregoing observations were the main considerations for the location and distribution of small tanks in the NCP and NWP, it is difficult to identify the reasons for the location of small tanks within a cascade in the SP. The occurrence of such a high proportion of abandoned tanks within the cascade further complicates the situation, thereby making further reasoning more complex and difficult. However, in the Bodagama cascade (cascade 5), the spillways of the two larger tanks namely the maha Aluthgam Ara Wewa and the Angunakola maha Wewa were situated on low relief, rock outcropping land.

According to Somasiri (1991) the location and distribution of small tanks in the Anuradhapura district of the NCP had been determined more by social factors and site features, rather than by the hydrological properties of the catchment. It is not known at which period a major proliferation of the presently existing small tanks took place within the individual cascades. One fact that is quite clear is that not all these smaller or micro tanks, especially in the NCP, were for purposes of irrigated paddy. Instead, they served a number of other multiple uses including augmentation of the ground water table in order to keep the domestic well water supply at a minimum level during the protracted dry season and as silt trapping tanks (Kuluwewa) during the rainy season, according to Tennakoon (1986).

There are no records or traditional knowledge available on the hydraulic design and storage capacity of the tanks. It is not known how the key hydrological parameters were determined, especially those relating to the amounts of rainfall, runoff and tank volumes. A body of empirical relationships would have been known at that period, which could have helped in determining the amount of storage that would have been possible within a water body created by an earthen bund of specific dimensions.

It must be remembered that by 400 and 500 A.D., very advanced hydraulic structures, which would have required a sound knowledge of some of the key hydrological relationships pertaining to rainfall, runoff and storage volumes had been designed and constructed. There is no reason to doubt that this body of expert knowledge that was available for major reservoir and sluice-channel construction could have been extended, with some modifications, to the design and construction of the smaller tank systems as well.

In respect of the construction of bunds, a careful comparative examination of the cross section of excavated bunds of the major irrigation works and of the medium sized village tanks reveals no special difference in the methods of earth work and earthen bund construction. However, there is a common relationship among all small tanks in respect of the shape and dimensions of the base, slope and height of the bunds.

One of the main differences between the major irrigation works of this earlier period and the minor tank systems was the design and operation of the sluices. The "cistern type" sluice of the major irrigation reservoirs of that early period were constructed of dressed stone, and brick and lime mortar on the outer section. These have been referred to as the Bisokotuwa and are regarded as unique and distinctive achievements of the ancient Sri Lankan hydraulic engineers. These stand out in contrast to the "Piston" type sluices that evolved and were perfected in Tamil Nadu according to Gunawardena (1984). Each of these two types 
was uniquely adapted to the hydrological environments of the dry zone of Sri Lanka and the semi-arid zone of Tamil Nadu.

The small tanks of the cascades, however, had simpler and less elaborate sluices-more commonly what is today associated as the "junction block" type (Begum, 1985) made of clay and burnt into "terra-cotta" hardness. Some of the somewhat bigger and older tanks, especially those at the lowest end of the cascade, had simpler forms of stone cut sluices that had been functioning up to recent times in few, scattered tanks in the NCP.

In summing up this section it is useful to draw on the foregoing discussions in relation to the 5 cascades that were studied. It could be seen that in all instances the bunds of the tanks have been constructed across the main and side valleys in order to collect and pond the runoff received from the adjacent upland. The tank density is mainly governed by the amount of seasonal rainfall and runoff and this is clearly visible in respect of both tank size and tank density in the different hydrological environments. Cascade 4, which is located in the intermediate rainfall zone, has the highest tank density and highest number of smaller tanks and cascade 5, which is in the driest environment of the semi-arid rainfall zone, has the lowest tank density. Cascades 1, 2 and 3, which are located within the modal dry zone environment, have the normal tank density.

In all instances, there is a spatial commonality in relation to the location of the irrigated lands, the permanently settled homestead and the use of the bund to link the settlements. The spatial distribution of the irrigated land and upland has been designed with a view to achieving the optimum agro-distance for agricultural operations. All tank bunds and sluices would have undergone some degree of rehabilitation at different intervals of time according to the needs and the resources available. The extent of Puranawela had been determined by the most reliable amount of water that could have been captured within a tank. The past spilling history, in terms of duration and amounts, would also give a good indication of the hydrological richness of the tank catchment area. The spill waters normally flow across the irrigated lowland of the lower tank and this reduces their surge velocity before they reach the adjacent lower tank.

A rudimentary on-field irrigation delivery system, especially in very small tanks has been practiced from ancient times and recent attempts to improve these have not been very successful because these lands are the habitual grazing grounds for herds of livestock throughout the dry season, after the harvest has been taken. The fact that only temporary fencing is found around the paddy tracts is a clear indication of its use as a common grazing ground for livestock — cattle and buffaloes. Therefore, it is not possible to have a permanent on-farm irrigation layout that could resist cattle trampling damage.

At best, in recent rehabilitation of small tanks, some durable improvements to the sluices and the main delivery segments of the delivery canals at their head-end portions are visible.

Ad hoc raising of bunds and spillways in recent times, by well meaning rehabilitation agencies, made at the request of farmers or else by politicians, have seriously disrupted the delicately balanced hydrology between the respective tanks within a cascade. No attempts have been made in the past to study the total hydrological relationships between all the bigger tanks within a cascade before rehabilitating individual tanks. This situation has been significantly improved following the recent studies conducted by the International Water Management Institute (IWMI). 
Improvements to the shape, size and quality of the earthen bunds have been effected in all instances where recent rehabilitation has been carried out. The standard rehabilitation design criteria recommended for small village tanks both by the Irrigation Department and the DAS has been adhered to as far as possible.

\subsection{Hydro System}

In respect of the hydrological balance, it is unclear on what criteria the relationships between the characteristics of the catchment area and the runoff pattern were considered during the medieval or ancient period. In a recent study involving a total of 240 cascades in the Anuradhapura district (Sakthivadivel et al. 1996) it was observed that only 104 of these cascades had the adequate catchment area that would supply sufficient runoff to the tanks in order to obtain a reliable irrigation supply that would ensure a cropping intensity of at least 75 percent. Although this may be considered a luxury standard by the ancient practitioners, it nevertheless indicates that irrigating paddy may not have been the primary goal of capturing the surface runoff in these tanks. Since there were other stable sources of food supply from rainfed chena cultivation, the primary purpose of this stored water would have been to first provide for human needs during the protracted dry season and second for irrigated paddy. Nevertheless, as will be seen later, there was the very pragmatic and sustainable Bethma tradition that enabled equity in sharing of limited water supply by cultivating only a portion of the irrigation command in seasons of low rainfall.

Somasiri (1991) considers that tank density is an important factor in respect of the amount of runoff that could be collected during the rainy season. He argues that at low tank densities, the siting of the tank is such that a large catchment ensures a higher supply of runoff water, and that at low tank densities irrigated agriculture becomes more stable. $\mathrm{He}$ further observes that with a further increase in tank density, the water supply becomes unstable because of limitations in catchment size, and this in turn leads to irrigated agriculture becoming more risky and economically unstable. It is also observed that in some areas of high tank density, a large number of command areas remain fallow because of limitations in water supply. He has also shown that the year to year fluctuations in the extent of cultivated area is very high in the Anuradhapura district which has the highest tank density as compared with the other districts which have a lower tank density. He concludes that tanks which have a catchment area of 9 ha per 1 ha.m. of storage have a more stable water supply.

It should be borne in mind that the present day utilization of the small tank water resources has been primarily targeted for paddy cultivation, and tank hydrologies are therefore determined with the main objective of supplying a minimum water duty for the paddy crop for the maha season. There is no strong supporting evidence that in the medieval traditional system, paddy cultivation or optimization of stored water for paddy was not the main objective. Therefore, considerations of hydrology that are adopted today for at least 75 percent probability of successful paddy cultivation during the maha season may not have guided the hydrological considerations of the earlier settlers who gave maximum priority to stored water for human and livestock needs during the protracted dry season.

It is therefore questionable whether we should judge a cascade performance on the basis of the cropping intensity achieved for paddy cultivation. The SP provides a good example of tank water being primarily used for needs of human settlement with rainfed chena 
cultivation being the primary agricultural activity. Here the cropping intensity for paddy is a secondary concern, compared to chena cultivation which is the primary concern.

The present day approach to hydrological design in the rehabilitation of small village tank systems is based on the publication of the Department of Irrigation titled The Development of Village Irrigation Works (Arumugam 1957). This has been subsequently updated by Ponrajah (1982) under the title Design of Irrigation Headworks for Small Catchments. This publication deals with hydrological and hydraulic design parameters, and design practices for embankments, spillways, anicuts and sluices for small catchments up to $51.8 \mathrm{~km}^{2}$ or 518 ha.

This manual outlines the procedure for determining the reservoir capacity and the irrigable extent based on the amount of rainfall and runoff as well as the distribution of such rainfall over the crop season. The seasonal runoff or yield is derived from the iso-yield curves prepared by the Hydrology Division of the Irrigation Department. The operation study is carried out using 75 percent probability of rainfall, in place of arithmetic mean of rainfall, since the latter tends to give an overestimate of the real expectancy value of rainfall in this highly variable rainfall environment.

Further refinements to the assessment of tank cascade hydrology have been made by Sakthivadivel et al. (1997) for rehabilitation planning, which include estimating the cascade outflow with a simulation model.

More recently Navaratne (1998) has shown that the observed water yields are much lower than the computed iso-yield values, and that on the average 15 to 25 percent lower catchment yield can be expected in the maha season. He further shows that there is 25 percent evaporation from the tank surface during the maha season and that seepage and percolation losses are higher than 20 percent as compared with the design value of 10 percent. He finally shows that irrigation issues under small tank systems are limited to 10 to 20 percent for the seasonal water yield, and that the irrigation potential for paddy under small tanks is therefore marginal.

The magnitude of sedimentation or siltation in village tanks has been discussed by Dharmasena (1992) and he also proposes the concept of partial de-siltation (1994) as an appropriate and effective method of small tank de-siltation.

\subsubsection{Groundwater}

The groundwater situation under small tank cascade systems of the NCP had been studied by IWMI (1996) with a view to identifying the agrowell potential in 50 cascades selected across 21 Divisional Secretariat areas. These studies were confined to shallow groundwater, which is presently tapped by the agrowells. The nature of distribution of this shallow groundwater as well as the amounts that could be safely extracted was studied in detail. Cascades 1 and 2 were also included in this study. The results of this study could be reliably extended to the rest of the NCP, NWP and SP, where small tank cascade systems occur. The area within which this groundwater occurs in the cascade, and the amounts that could be safely extracted can now be calculated with a high degree of reliability. The main threat to this highly precious and limited resource of shallow groundwater, comes from the rapid proliferation of agrowells in the NCP. There is no similar threat in the NWP or SP. The linkage between this shallow groundwater body and the stored surface water in the small tank has also now been better 
understood. Methods for the safe and sustainable use of this groundwater both for agrowells and domestic use have been proposed by IWMI, and these have been accepted by the different government agencies (de Silva et al. 1999).

It should, however, be noted that the deeper groundwater that is available from deep joints and fractures in this hard rock area is more sporadic in its occurrence and is limited in quantity. This groundwater is being exploited by deep-bore tubewells, in and around urban and semi-urban settlement areas for domestic use.

\subsubsection{Water Quality}

Water quality studies have been conducted on the deep-bore tubewells by the National Water Supply and Drainage Board (WS\&DB) from the mid-1980s, while studies on shallow groundwater and surface water quality have been carried out more recently by IWMI as well as some national agencies. The results of the studies by COWI consultants (1993) on deep tubewell water show tolerant levels of hardness and very little bacterial pollution. However, sporadic areas of deep groundwater with high fluoride content have been identified and demarcated.

Results of shallow groundwater analysis by Ariyabandu (1993), Kendaragama (1994) and IWMI (1996) show that the water quality of agrowells located under major tanks and minor tanks have nearly the same values with Sodium Absorption Ratio (SAR) values ranging between 3.5 and 4.0, and Electrical Conductivity (EC) values between 1.0 and $1.5 \mathrm{ds} / \mathrm{m}$. While these were values were reported at the end of the dry season when concentration was at its highest, much lower values were recorded during the end of the wet season. These values were not very high and fell within the safe range.

Results of studies conducted by IWMI (1996) on the water quality of 25 small tanks in the Anuradhapura district through water samples collected at the end of the dry season show SAR values of around 6.0 and EC values around $1.25 \mathrm{ds} / \mathrm{m}$ which falls within the safe range.

The nitrate values of water samples from both agrowells and small tanks show values comparatively higher than for the major tanks but still below the critical standard limits set by WHO. Preliminary results also show a concentration of soluble salts especially potassium, following the high evaporation of the surface water in small tanks over the usual dry season from May to August.

\subsection{Maintenance and Tank Use}

Across all 5 cascade systems studied, the traditional method of tank maintenance was under the ancient Rajakariya system carried out by the collective effort of the farmers under the direction of the Velvidane. With the abolition of the Rajakariya system under British rule in 1832, this traditional maintenance system fell into gradual decline, but it had been revived at different periods both prior to and after independence in 1948. It is now practiced in a modified form in different degrees, according to the leadership qualities of the Velvidane and the cooperation received by the land holding farmers. The general procedure is described below. 
At the Kanna meeting (pre-seasonal meeting of farmers) a decision is made regarding the maintenance of the headworks and the distribution network, including the fencing of the area that will be cultivated in the ensuing season. The main item discussed is the repair and maintenance of the tank bund. Minimal maintenance to the bund, which gets worn down by rain and cattle trampling, is done by excavating earth from the dry tank bed before the onset of the rains. The extent of cleaning of the bund by each farmer on the basis of their land holding will be measured by the Velvidane, and numbered pegs will be fixed on the bund. Each farmer is then informed about the quantity of work, on a fixed standard measure, that they should carry out in repairing the bund. If there are any canals that have to be cleared and repaired, these too would be measured and given to each farmer to complete in proportion to the extent of his holding, the length of fencing to be done is also similarly assigned to each land holding farmer. If any farmer fails to comply with these allotted tasks, he can be punished by the Velvidane. Under British rule, the punishment powers of the Velvidane were transferred to the Gamsabhawa or rural court, but this proved ineffective and it led to a decline in discipline in tank maintenance.

Any urgent repairs caused by a flood were met by the collective effort of farmers. During the period of British rule drought relief aid was given to farmers during prolonged droughts to carry out repairs on village tanks. Food aid or cash was provided to the farmers on condition that they were able to produce some output in the form of bund rehabilitation or road repairs. These activities were organized by the Velvidane and have been carried out to the present under different project names and under different donor-aid schemes.

In 1958, under the Paddy Lands Act, the Velvidane position was abolished and a Govi Karaka Sabha (farmer committee council) with a Palaka Lekam (administrative secretary) was appointed. With this, the mode of compulsory labor maintenance virtually collapsed, but in most places the voluntary Velvidane system was able to continue. After several misguided attempts, the Farmer Organization (FO) system came into operation in the late 1980s, and this has continued up to now with the FOs functioning with the help of the former Velvidane. Under some donor funded projects, all maintenance work is handed over to the FOs.

In Pihimbiyagollawa cascade (cascade 1) the de-silting of the tank bed, repairing of the bund and canal system takes place every year after the yala cultivation. All land owner farmers are given their share of tasks-measured and marked. Standard pit measurements according to the number of families holding land are calculated. Each pit is equal to 2.10 cubes, with each family having to excavate about 12 pits each season for bund improvement. Many elements of the traditional Velvidane system are still prevalent under cascades, perhaps due to their distance from centers of local administration.

In cascade 2, the maintenance is done by both FOs and the Velvidane. Cascade 3 follows the same system. In cascade 4 there is a marked difference in the organization which takes up the maintenance of tanks and roads. Here there are four well established Maranaadhara Samithi or funeral assistance committees, which have assured voluntary financial contributions and are very active and sustainable. They carry out their maintenance tasks very competently. In cascade 5 the maintenance in the bigger tanks is done by the DAS or the DI, while in the smaller tanks the FO have been operative since the early 1990s.

In the command areas of tanks that have a higher cropping intensity, as in cascade 4, and also in Mahakanumulla (cascade 2), the on-farm layout plots and Liyaddas (micro-bunds within paddy fields) are kept in a more permanent form, whereas in cascade 5 in the SP, 
because of the drier environment and also the higher intensity of cattle grazing, the microbunds are in poorer shape.

In respect of water issues themselves, the decision for the first date of issue for land preparation is made at the Kanna meeting, and a continuous issue of water is made for a period of 3-4 weeks. Thereafter, depending on the rainfall distribution, the main sluice is operated on and off, as and when the farmers feel the need to irrigate the paddy land and keep it in a saturated state. More recently, the decision to commence cultivation and decisions on water issue dates are made by FOs-wherever they have been successfully instituted. The water releases, however, are mainly done by the traditional Velvidane, who receives a reimbursement for his labor which is called Salaris (Sinhala equivalent for salary) which can take the form bushels of paddy or its equivalent in cash.

Apart from irrigation for paddy, tank water is also used for livestock, bathing, washing and other domestic uses. Fish rearing, and fish culture is presently at a very rudimentary stage but plans are ready for more intensive inland fisheries development plan. Jayasekera (1997) mentions that fish culture in seasonal village tanks has great potential, especially in water bodies that can hold an adequate volume of water for a period of 6-8 months of the year. He further states that an average yield of $750 \mathrm{~kg} / \mathrm{ha}$ of fish can be achieved in the tanks because grazing cattle and decaying vegetation enrich the waters leading to the formation of fish food organisms. Thayaparan (1982) mentions that a production of 750-1,000 kg/ha per season could be obtained from these small tanks without any extra inputs other than restocking with fingerlings, and that with very little infrastructure investment a quick and dependable method of increasing fresh water fish production could be achieved.

The tank bed, with its gradually receding tank water level in the dry seasons constitutes the main productive dry season grazing ground for village cattle. Because of the better moisture regime in the soil within the tank bed and foreshore area, there is an enhanced production of herbage on this receding tank shore line area in the dry season. This facilitates a higher carrying capacity for grazing herds than the adjacent rainfed upland, which dries up very rapidly during the dry season. The cattle droppings in turn also get washed down into the tank bed and subsequently enrich the tank water which provides for the formation of fish food organisms and also helps to provide nutrients for plants.

Brick making is also carried out in these parts of the tank bed where surface clay deposits of the acceptable particle sizes can be identified. These usually occur on the lower ends of both banks rather than in the central area, which also gets replenished every 10-15 years. The quantities of brick usually made are just sufficient to meet the domestic needs of new housing within the cascade area and not for commercial purposes or for sale outside. 


\section{CHAPTER 5}

\section{Institutional Management and Integration with Local Farming Systems}

\subsection{Evolution of Present Management Structures}

With the abolition of the Rajakariya system in 1832, a decline in the repair and maintenance of minor irrigation works began. Since water was a more scarce resource than land, there were more tenurial customs connected to water than land. All decisions pertaining to irrigation and cropping were made and implemented through the Gamsabhawa headed by the Gamarala (village headman) (Leach 1980). With the abolition Rajakariya, the function of the Gamsabhawa and Gamarala became inactive and the customary rules fell into decline. The subsequent deterioration of village tank irrigation systems in this period is best described and discussed by Silva and Vidanapathirana (1984).

Being concerned about this deterioration, the British administration recognized the need to revive at least the customs and practices that went along with the repair and maintenance of minor irrigation works. The first Paddy Lands Irrigation Ordinance No. 9 of 1856 was enacted to fill this gap. Its principal aims, which were very cogently articulated, were as follows:

a. "to facilitate the revival and enforcement of ancient customs regarding irrigation and cultivation of paddy"

b. "to remedy the non-observance of many ancient and highly beneficial customs connected with irrigation and cultivation of paddy lands"

c. "to remedy difficulties, delays and expenses attending the settlement of differences and disputes among cultivation relating to water rights and obtaining redress for violation of such rights in the ordinary course of the law"

It was recognized that the institution of the Velvidane was essentially the linchpin of the whole system. In the local idiom, the term Velvidane means "the executive of the paddy lands". His role was that of an organizer, rule enforcement officer and even an arbitrator or judge. The Velvidane's position was further reinforced by the revival of the Gamsabhawas or rural courts which though simple in form and summary in action, were easily understood 
and respected by the village communities. The main emphasis of these Gamsabhawas was to seek amicable settlement in place of litigation. The Gamsabhawas functioned under the administration of the Assistant Government Agent of the district and they had power to enforce fines for breaking rules and also to impose punishments for any infringement of accepted rules and customs.

The original Irrigation Ordinance of 1856 underwent at least seven revisions in 1867, 1889, 1906, 1908, 1915, 1917 and 1946, over a period of 90 years. By the time of independence in 1948, the Velvidane's position had become entrenched in the village administration through a period of nearly 100 years of operation. At least in theory, the Velvidane was elected by a majority of the farmers in the village, and once appointed, he held office until he resigned or retired or got dismissed by the Government Agent.

According to the Irrigation Ordinance of 1946, the duties of the Velvidane included the following:

a. to attend to all matters connected with the irrigation and cultivation of the lands within his division and the preservation of rights and the maintenance of irrigation works.

b. to prevent, as far as possible, any act or omission which is contrary to any of the rules or regulations that are in force under this Irrigation Ordinance, or to establish customs relating to irrigation or cultivation.

Although there was no monthly remuneration for the Velvidane, he was permitted to collect a Salaris from shareholders, in proportion to the land ownership and yield at the time of harvest, and he therefore had an incentive to ensure that the crop did not fail.

Towards the latter part of the British rule, the authority of the Velvidane had declined considerably because some of the powers of the Velvidane were taken over by the village headman and this also made the enforcement of communal action more difficult. There was some degree of friction between the village headman and the Velvidane in the discharge of their powers.

The operation and management of small village tank systems have undergone a series of changes since 1950, which were introduced by successive governments mainly with a view to increasing the agricultural productivity under these small tanks. Many of these changes were brought about without a proper assessment of past experience and accumulated experience of local traditions. The replacement of the Velvidane system by the Cultivation Committee (CC) of 1958 initiated a process of government intervention in small tank management. With the introduction of the Paddy Lands Act of 1958, the minor irrigation system became the responsibility of the Agrarian Services Department. The organizational changes that subsequently took place in the successive periods are shown in summary form in table 6. 
Table. 6. Organizational changes in management of small irrigation systems.

\begin{tabular}{|c|c|c|c|}
\hline Year & Institution & Supervision & Duties and responsibilities \\
\hline $\begin{array}{l}\text { Before } \\
1958\end{array}$ & Velvidane & $\begin{array}{l}\text { Assistant Government } \\
\text { Agent (AGA) }\end{array}$ & $\begin{array}{l}\text { Irrigation, water management, } \\
\text { paddy cultivation }\end{array}$ \\
\hline 1958 & $\begin{array}{l}\text { Cultivation } \\
\text { Committee }(\mathrm{CC})\end{array}$ & $\begin{array}{l}\text { Department of Agrarian } \\
\text { Services (DAS) }\end{array}$ & $\begin{array}{l}\text { Planning and implementation of } \\
\text { agricultural development and } \\
\text { irrigation maintenance }\end{array}$ \\
\hline $\begin{array}{l}1972 \text { to } \\
1977\end{array}$ & $\begin{array}{l}\text { Agricultural } \\
\text { Productivity } \\
\text { Committee (APC) }\end{array}$ & DAS & $\begin{array}{l}\text { Irrigation and paddy cultivation } \\
\text { and other agricultural activities }\end{array}$ \\
\hline $\begin{array}{l}1977 \text { to } \\
1979\end{array}$ & $\mathrm{CCs}$ and $\mathrm{APCs}$ & \multicolumn{2}{|c|}{$\begin{array}{l}\text { Dissolved consequent to change of government's political } \\
\text { philosophy }\end{array}$} \\
\hline \multirow[t]{2}{*}{$\begin{array}{l}1979 \text { to } \\
1991\end{array}$} & $\begin{array}{l}\text { Agrarian Services } \\
\text { Committee (ASC) } \\
\text { replaces APC }\end{array}$ & $\begin{array}{l}\text { Commissioner of Agrarian } \\
\text { Services }\end{array}$ & $\begin{array}{l}\text { Irrigation and paddy cultivation } \\
\text { and supply of inputs }\end{array}$ \\
\hline & $\begin{array}{l}\text { Yaya Niyojitha } \\
(\mathrm{YN})\end{array}$ & $\begin{array}{l}\text { Cultivation Officer } \\
(\mathrm{CO})\end{array}$ & $\begin{array}{l}\text { Most functions similar } \\
\text { to Velvidane }\end{array}$ \\
\hline $\begin{array}{l}1991 \text { to } \\
\text { present }\end{array}$ & $\begin{array}{l}\text { New approaches } \\
\text { Farmer Organizations } \\
\text { (FO) }\end{array}$ & $\begin{array}{l}\text { Divisional Officer } \\
\text { (DAS) } \\
\text { and Velvidane }\end{array}$ & $\begin{array}{l}\text { Rehabilitation, FO and irrigation } \\
\text { management, supervising by FO }\end{array}$ \\
\hline
\end{tabular}

\subsection{Present Management Structure and Practices}

While the stated official responsibility for the minor irrigation system lies within the DAS, most of this responsibility is devolved to FOs and the Velvidane position is also retained.

The institution of the former Yaya Niyojitha (person in charge of a tract in the command) was in most ways a return to the earlier Velvidane system. The Yaya Niyojitha is now referred to as the Velvidane by those who have grown accustomed to use that title for anyone who performs the former functions of the Velvidane.

The recently formed FO is now held responsible for organizing and maintaining work on the channels as well as the tank bund and other structures. It is also responsible for implementing the decisions made at the Kanna meeting, and one of its functions is also to allocate water from the tank and to enforce the necessary discipline in its use. The Agrarian Services Act has provision for taking action against those who violate any decisions taken at the Kanna meeting.

There is no clear evidence that the FO has been able to gain the whole hearted acceptance of the farming community or whether they have adequate powers to enforce punishments for defaulters. They are also not in a position to take swift and decisive action on conflicts. However, they have been quite effective in disaster management situations.

The Kanna meeting is undoubtedly the most important decision making body which operates at the tank level. It is a meeting of all farmers who cultivate land under the tank, and it is held every season well before the onset of the maha or yala rains. Summons for 
meetings are made by the Divisional Officer (DO) and this meeting is presided over by an official of the DAS or his representative. Attendance at this meeting is not compulsory. At times, if required a Technical Officer (TO) of the Irrigation Department is also present at this meeting if more complex irrigation issues are to be discussed. The more important decisions taken at the Kanna meeting relate to the following items:

1. Extent of paddy land to be cultivated.

2. Date of proposed commencement of cultivation season.

3. Commencement date and completion date for following activities:

- first and last date for water issue

- cleaning of bunds and channels

- repair and cleaning of sluice outlets

- erection of fences and task allocation

- dates for ploughing and sowing

- variety and age classes of paddy to be sown

The meeting is expected to be conducted in a democratic manner and the decisions are taken collectively by all the farmers attending the meeting. As a usual practice, the Puranawela gets priority in terms of water issues. The extent of Akkarawela to be cultivated would be decided according to the amount of rain and runoff water that would be collected in the tank by the middle of the maha season.

Although the main rationale for the Kanna meeting is one of being able to set the schedule in order to make optimum use of the highly variable and limited water that will be collected in the tank, there are many deviations that take place from the agreed decisions made at the Kanna meeting. Such deviations lead to a non-optimum use of the limited tank water supply and frequent water shortages when maturing the sown crop.

One of the main reasons for these deviations is the poor attendance at the Kanna meetings because of the top-down regimentation exercised by the DO and the CC memberssometimes almost ordering the Pangukarayas (Shareholders) to attend the meeting. This is something that the Pangukarayas resist. The other problem is the loosely defined authority of the FO. Because of the poor attendance at the kanna meeting, the all-binding character of the Kanna meeting decisions gets diluted and results in a disruption of the agreed rhythm of activities. The present FO's powers and authority is not clearly defined and understood like that of the former Velvidane. There is no provision for the FO to take quick action against minor offences.

Invariably, not all decisions and agreements arrived at the Kanna meeting are adhered to. This results in many kinds of disruption to the smooth rhythm of sequential activities. Most often, the decision to initially cultivate the Puranawela is dishonored, and the more powerful farmers with significant extents of Akkarawela start working them with the first rains. This results in cultivating both Puranawela and Akkarawela. Because of the disproportionate extent of land thus cultivated, a shortage of water is experienced towards the final stages of crop growth and this results in either partial or complete crop failure according to the severity of water shortage. 
Wastage of water supply is also an additional reason for crop failure. Water is used extravagantly under continuous flow conditions and no serious effort is made to conserve as much water as possible for the subsequent yala season. Continuous flow of water from the sluices also hinders planned water savings and this is largely caused by most tank sluices not being fitted with padlocked gates or locking devices.

With regard to the 5 cascades that were studied, the foregoing management practices operate at varying degrees of efficiency and inefficiency. In Pihimbiyagollawa (cascade 1) the recently instituted FO system is believed to be functional. However, there is no clear evidence that this FO is well established nor has it been able to inspire the confidence of farmers who generally hint that they find it easier to relate to and operate with the previous Velvidane setup. In general it is the well established Velvidane system that operates successfully within this cascade.

In Mahakanumulla (cascade 2), the former Velvidane system continues in most of the Kanna meeting decisions and operations-mainly in water issues and deliveries. The FOs are now well established and are mainly involved in carrying out contracts given by the DAS for rehabilitation and repair works. Some water management operations are carried out both by the Velvidane and the FO personnel.

In maha Nanneriya (cascade 3), the situation is very similar to that of the previous cascade. Almost all the bigger and medium tanks have FOs formed under them. Operation and maintenance is now done by these FOs in partnership with the Velvidanes. Despite the recent establishment of FO, it is again the Velvidane system that essentially functions within this cascade as well.

In maha Girilla, Olupeliyawa (cascade 4) a somewhat different situation exists. Some kind of institutional arrangement exists only in tanks with a waterspread area of more than 10 ha. The smaller tanks, in turn, are sometimes individually owned or else are individually operated by some families on hereditary claims. The medium and bigger village tanks are managed both under the Velvidane system and different forms of FOs, such as the Maranadhara Samithi or funeral assistance committee, which undertakes the maintenance of the rural road network as well in this cascade. The smaller tanks are, for the most part, individually operated.

Bodagama (cascade 5) stands out in comparison to the previous four cascades in that its past and recent history have been quite different, which is characteristic of this region. The village headman rather than the Velvidane occupies an influential and decision making role within the village community. This was because, rainfed chena cultivation was the major, rather than the secondary, activity in this southern region compared with the NCP and NWP. Therefore, the village headman played a more important role in the allocation and supervision of the permits for chena and related procedures. The Velvidane, though nominally present, had only a very minor role to play in tank administration.

\subsection{Integration with Local Farming Systems}

Besides wet paddy cultivation in the lowlands under irrigation, the other major traditional farming activity had, and has been, rainfed chena cultivation on the unirrigable upland. There had been little constraint to the availability of land for chena cultivation in the past, until 
around the 1950s. During the maha season each family had sufficient resources to cultivate 0.80-1.21 ha of chena land, in addition to the $0.40-0.80$ ha of irrigated paddy land. With population increase, and also the increase in the frequency of the chena-forest cycle, the amount of land available for chena cultivation has been considerably reduced. The quality of the forest land available for selective cutting and burning has also been considerably reduced. However, the extent of lowland wet paddy land in the Puranawela has remained static - simply becoming more fragmented. There has been only a little increase in the intensity of cultivation either on the paddy land or on the chena land over the past 50 years. This has led to an increase in land pressure within these cascades. Also, the distance from the homestead to the chena lands has increased, which in turn affects the productivity of chena cultivation. A general picture of the increase in population pressure is available through some selective figures for each of the 5 cascades in chapter 7 .

A careful examination of the trends over the last 50 years shows a gradual displacement of some of the traditional local farming systems and their replacement with new modes of farm production. Such major changes or replacements have taken place in two dominant cropping systems, the chena cultivation on the uplands and irrigated paddy cultivation in the lowlands. Changes in respect of the Puranawela cultivation are discussed first.

In cascades 1 to 4 , there has been a very significant increase in the extents of Akkarawela over Puranawela. The present extents of Puranawela and Akkarawela in a sample tank from each cascade are given in table 7. It should be noted that during the early 1900s, the extent of Akkarawela was very small, compared to the Puranawela.

Table 7. Extents of Puranawela and Akkarawela in sample tank.

\begin{tabular}{clcc}
\hline Cascade & Tank & $\begin{array}{c}\text { Puranawela } \\
\text { extent (ha) }\end{array}$ & $\begin{array}{c}\text { Akkarawela } \\
\text { extent (ha) }\end{array}$ \\
\hline 1 & Thambalagollewa & 34 & 59 \\
2 & Alisthana & 26 & 22 \\
3 & Nochchiya & 19 & 15 \\
4 & Hidogama & 20 & 14 \\
\hline
\end{tabular}

The Akkarawela is the newly developed or asweddumized paddy land immediately adjacent to and above the older traditional Puranawela paddy land. In a few instances, where the micro-elevation permits, or where the sluice levels of the rehabilitated tanks have been raised, a portion of these lands are able to obtain a part of the irrigation supplies. Areas that cannot obtain such irrigation supply are essentially rainfed paddy land that makes use of both direct rainfall as well as standing water that is stored in these lower valleys. The phreatic water table, in addition, augments the water requirement of the paddy crop in the Akkarawela lowland. On the whole, since the Akkarawela fields are located at the periphery of the Puranawela, the seepage and conveyance losses are higher at the Akkarawela than at the Puranawela. This has resulted in severe competition for the limited water supply for irrigated 
paddy. It has also led to a gradual deterioration of the Bethma, or the traditional practice of water sharing during seasons of water shortage.

Despite the decisions made at the Kanna meeting, the decision to cultivate the Puranawela first is dishonored, and those farmers who own considerable extents under the Akkarawela start working on them expecting sufficient rainfall for the rest of the season. In most situations, the farmers owning Akkarawela outnumber those owning Puranawela, and work on the Puranawela gets delayed or even abandoned in some seasons. The overextension of the land preparation period results in a shortage of water towards the final stages of the crop growth period and this often results in partial or complete crop failure. Furthermore, the continuous and excessive flooding of fields during early stages of crop growth for weed control damages the sluices and nonadherence to rotational water issues combine to lead to an aggravation of water scarcity towards the latter part of the maha season.

In sum, it could be said that in the irrigated Puranawela lands, there has been more disruption rather than integration with traditional practices and customary laws.

In traditional chena cultivation, the earlier integration with other components of the local farming systems has weakened. Traditional rainfed chena cultivation which was primarily a subsistence farming practice has undergone very significant transformation over the recent decades and is now a semi-commercial activity. Whereas earlier, even the chena activities were carried out as a communal effort of shared labor and other resources, it has now moved more in the direction of individual enterprise. This is beginning to have significant repercussions on the land use pattern and land conservation practices that existed earlier on this unirrigable upland.

A further cause disruption has been agrowell development over the last decade. While helping to improve farmer incomes, and also profitably exploit the shallow groundwater supplies that were hitherto unutilized, it has given way to greater individualism and nonobservance of the finely balanced traditional seasonal cropping patterns between the rainfed upland and the irrigated lowland.

Traditional cattle and buffalo rearing practice was a free range grazing practice, with the roaming herds coming to rest in the village compound at night. This practice still continues with a greater intensity of grazing on the paddy fields, especially during the off season. The quality of the cattle has been significantly upgraded by artificial insemination and there is more milk production and consumption within the village than in the past. Fishing practices remain rudimentary and unchanged, but there are plans to stock and rear fish in cascade 5 . 


\section{CHAPTER 6}

\section{Recent Changes Due to Government Interventions}

In this chapter the recent changes that have taken place in each of the 5 cascades are described individually and a general discussion across all 5 cascades is carried out.

\section{Pihimbiyagollawa-Cascade 1}

Basic investments to improve the overall infrastructure of the cascade area as well as tank rehabilitation have been taking place since the 1920s. Repairs and improvement to tanks along with improvement of the rudimentary road network was mainly done in order to improve agricultural productivity within the area and to minimize the need for food imports to the country. At the same time, the need for improving the health standards of the people in order to enhance agricultural productivity was also recognized because certain debilitating diseases such as malaria and yaws were almost endemic. The interventions described above were all carried out by various government agencies, which though thinly spread during that period, were closely monitored and supervised by the state bureaucracy.

Having improved basic transport and health amenities, educational investments were made around 1930 when government secondary schools were opened at Ratmalgahawewa and Pihimbiyagollawa. The maha Vidyala (high school) at Thambalagollewa was started in 1965. With schools coming up, the literacy rate in the area is now around 90 percent. The two main roads serving this area from the west and the south, were tarred in 1970 and electricity was provided in the mid-1990s.

Almost all the tanks with a waterspread area of more than 10 ha have undergone some measure of rehabilitation, while the two largest tanks of Thambalagollewa and Pihimbiyagollawa are due for a comprehensive rehabilitation under the National Irrigation Rehabilitation Project (NIRP) during this year.

Good quality drinking water has been a long-standing problem in this area with only a very few good quality drinking water wells available for domestic use. Salinity levels of most wells tend to increase during the dry season. During the1986-1992 period around 20 successful tube wells were constructed at various points to minimize the walking distance for women to satisfy their domestic water needs.

Tractor ploughing has virtually replaced the traditional plough and buffalo, except in very small tanks. Furthermore, cattle and buffalo rearing on a free range system is difficult because educated youth tend to shun traditional cattle rearing work.

There has been very little private investment made in any type of enterprise within this cascade, except in improved house building which is the main priority investment area for persons employed in the army and other security forces. There are very few employed within the private sector, and even less in foreign employment in the Middle East. More than 50 percent of the outside employment comes from the state army and security forces. 


\section{Mahakanumulla-Thirappane-Cascade 2}

The opening up of the Anuradhapura-Kandy main road in the latter part of the 1800s made only a small impact on the way of life within these two cascades. It was the opening up of the internal gravel roads during the 1920s that brought life in these cascades in contact with local trade and commerce.

In the Thirappane cascade, which borders the Kandy-Anuradhapura main road, the people living in the traditional village homesteads of Thirappane and Alisthana tanks moved up to the main road and started settling along the roadside. The houses in these new settlements had improved sanitary conditions and the people also began to have better access to trade and communication. In contrast, the village settlements further upstream like Vendarankulama, Badugama and Bulankulama remained in isolation until the improvement of the gravel road connecting them to the adjoining Mahakanumulla cascade in the early 1970s. The biggest change has taken place in the Meegassama tank which is located midway on the main valley of this cascade, where its capacity has been increased by raising its bund, thus resulting in almost a four fold increase in its command area from 9-36ha.

Improvements to the network of gravel roads have been made from time to time under drought relief aid by government funds and more recently by the Anuradhapura district IRDP and other aid projects. This has enabled a greater degree of mobility and an increase in the growing of chena crops that have a good market demand.

The largest tank in the adjacent Mahakanumulla cascade, located in the main valley, had been rehabilitated first in 1935 and subsequently in 1958, 1976 and 1997. It now serves a command area of 79 ha and supports 125 families settled under it. The rehabilitation in 1958 was almost a restoration because this tank had breached during the great flood of December 1957.

In the earlier part of the twentieth century, the general government policy was to rehabilitate only the larger tanks located along the main valleys of cascades. But following the various drought relief and related support schemes which came in after the World War II period, even the smaller tanks on the side valleys, which supported more than 20 families started receiving various forms of assistance for rehabilitation. As a result, more than 90 percent out of a total of 9 tanks in the Thirappane cascade, and 75 percent out of a total of 25 tanks in the Mahakanumulla cascade have now been rehabilitated.

Almost the entire gravel road network within both cascade areas is presently in very good condition, and regular maintenance of these roads is being carried out by the local administration. This is in striking contrast to the situation that existed up to the 1960s when even the rudimentary gravel road network that existed in this area was in a state of complete disrepair and neglect. As a result there has been accelerated economic development taking place over the last 15 years.

The other supporting services within the area of these two cascades are also at a comparatively advanced stage. The Thirappane and Walagambahuwa high schools provide good quality education and literacy levels are over 95 percent in this area. The earlier dispensary at Maradankadewela located around the head end of these cascades has now been upgraded to the level of a district hospital. Rural electrification has been extended in recent years to 
cover 90 percent of the Thirappane cascade, and 80 percent of the Mahakanumulla cascade. Although there had been no serious constraints with regard to the availability and quality of drinking water, during the period from 1994 to 1996 several tube wells have been provided in the more densely populated segments of the cascade. On the whole, the infrastructure facilities are fairly advanced within these cascade areas, providing the settlers with a good living standard.

A recently opened private sector garment factory at Thirappane provides daily employment to around 450 people, while a training center for drivers and machine operators has helped to further link the Thirappane cascade to the new economy emerging in this region. However, there is sufficient opportunity for employment in agriculture and cattle husbandry in this area. There are also initial signs of inland fishing development.

\section{Maha Nanneriya-Cascade 3}

The past history of this cascade is distinctly different from the previous two. It had been in a very underdeveloped or in a semi-abandoned state up to the latter part of the nineteenth century. Most parts of the cascade were covered in thick jungle with only a few settled inhabitants eking out an existence under partially abandoned tanks. There were three subsequent spurts of development, the first starting in the 1890s with the renovation of the main maha Nanneriya tank with a waterspread of approximately 121 ha. This, along with the development of the railway line to Anuradhapura and Jaffna and the location of the important Galgamuwa railway station close by helped open up this backward area.

By the 1930s the other 8 main tanks within this cascade such as the Molewa, Nochchiya, Ihalagamwewa, Thambere, Ihala Nanneriya, Kudawewa, Kohoman Kulama and Nallachchiya, each of which had a waterspread of more than 20 ha, had been adequately rehabilitated and people settled within them. This also resulted in a dramatic increase in the population of this cascade. With the new developments taking place around the Galgamuwa railway complex and the town after the 1930s, the settlers in these rehabilitated tanks were able to sell their chena and other surplus commodities to vendors around Galgamuwa. By the middle of the twentieth century agriculture, both irrigated paddy and rainfed chena, had become economically viable and a steady and reliable market was available with the expanding trading activity of the nearby Galgamuwa township. Government health services were present in the form of a maternity home that was later upgraded to hospital status. A rigorous antimalaria campaign helped to totally eradicate malaria by the 1960s. Surveyors and engineers from the nearby irrigation training institute are also present in this area-carrying out training field surveys.

By the late 1960s the second spell of development activities commenced. The government invested in the road network both within the cascade and the two main roads linking it to the nearby trading townships. A special development was also taking place in the Kohamankulama tank which had a high population. Land rights were given to farmers to grow teak plants on land given on chena permits. The trees could be subsequently owned by the farmers. This was, however, not replicated under any other tank in this cascade, probably due to the nonavailability of sufficient extents of chena land bordering the other tanks. 
The rest of the infrastructure investments in schools, hospitals and post offices also took place during this second phase of development. By the late 1960s regular buses started on the main and secondary roads. This attracted people to shift to the roadsides and start ribbon type of unplanned homestead development along the roadsides. This also encouraged outsiders to come into this area and settle along the roadsides.

During the period from 1970 to 1990 , a rapid change in lifestyles and settlement patterns had begun. With the construction and development of the major Inginimitiya irrigation and settlement project located further downstream within the Mee Oya basin, roads improved and a rural electricity network was also established. People started moving out of the tank village settlement on to the roadsides which had better services and they also began to seek nonfarm sources of employment. These were available locally within the government departments around Galgamuwa, as well as in Middle East employment opportunities.

A marked decline in agricultural activity and enterprise was observed during the period described above and the situation remains the same today. Income from agriculture related activities is now diminishing in this cascade and land fragmentation and illicit forest clearing are increasing. The younger generation is seeking forms of non-agricultural employment because agriculture is not considered very profitable any more. A complete transformation of the productive small tank village production system has taken place within this cascade.

\section{Maha Girilla-Olupeliyawa-Cascade 4}

Compared to the 3 previous cascades, maha Girilla-Olupeliyawa enjoys a more benign physical and hydrological environment due to its location within the intermediate zone (agroecological region IL3) (figure 5). Although it is not known what conditions prevailed within this cascade between the 1300 and 1700 A.D., oral tradition here implies that there had been a continuous settlement, through this "dark period", at a very rudimentary level. The main battle for survival had been more with disease and pestilence rather than hydrological inadequacy or drought or crop failures.

Much of the infrastructure within this cascade had been in position for a longer period than in the previous cascades and it is evident that rehabilitation and resettlement had commenced much earlier in the British rule period. It is claimed that several of the abandoned tanks were renovated by the resident people sometime in the late 1700s and that this process was further accelerated by the British administration during the latter 1800s and the early 1900s. At least, by World War II, almost all the present tanks were said to be functioning in some form or the other. In fact, during the food shortage experienced during World War II, this cascade experienced a prosperous economy because of its surplus paddy and other types of food production, according to the information provided by elderly residents here.

By the early part of the twentieth century, government assistance had been provided for substantial rehabilitation of the four bigger tanks of the maha Girilla cascade: Kadawalagedera, maha Girilla, Hidogama and Kotuaththawala, and for the two bigger tanks of the Olupeliyawa cascade. The dressed stone masonry employed in the spill and sluice structures in these tanks are typical of the construction style of that period.

Keeping in mind that there is a total of 47 tanks of all sizes in the maha Girilla cascade, and a total of 21 tanks of all sizes in the Olupeliyawa cascade, almost all the tanks with a 
waterspread of more than 6 ha had been provided with some form of government assistance for rehabilitation or improvement. There are 28 small tanks with a waterspread of less than 6 ha in the maha Girilla cascade and 12 small tanks in the Olupeliyawa cascade. Rehabilitation of these tanks has been carried out mainly by farmers and land owners. During the period from 1970 to 1977 all the minor tanks in both cascades were rehabilitated and improved. In most of the tanks the Full Supply Level (FSL )has been increased in order to impound more storage, but much of this has been minimized because of silting.

Except for a few internal gravel roads, all other existing and frequently used roads in these cascades were made during the British administration. These were gravel roads which have now been improved. The Nabadawewa-Girilla road was improved to a Village Council (VC) level road during 1965-1970, and a part of this road up to maha Girilla was tarred during the past five years.

The Girilla government school was started in 1930 and has been brought up to high school status during 1965-1970. This school serves the educational needs of both cascades and it has produced over 500 graduates. The Girilla dispensary which was set up in 1930 has been now improved to the status of a maternity hospital. Rural electrification reached this cascade area in the 1980s.

In 1988, with the opening of the "Sirisetha Gama" under the Gam Udawa program (government initiative for providing shelter for the needy), part of the chena area was acquired by the government and 100 houses were built with all supporting facilities for a village-type settlement. The houses were allotted to people from within this cascade and access roads were also provided by the state.

Traditional chena cultivation has almost disappeared from this area. The more moist upland has been converted to coconut plantations over the last 50 to 75 years, and also to homestead settlements over the last 20 years. Since agricultural employment opportunities are limited within the cascade, the younger generation is seeking many avenues for nonfarm employment. The women work in nearby garment factories and the young men practice skilled labor like carpentry, masonry and motor mechanics because of the increasing opportunities evolving in these fields. There is also migration out of this cascade to nearby towns and other rural-urban centers in the district.

\section{Bodagama-Cascade 5}

When compared with the 4 previous cascades, Bodagama experiences a much more hydrologically stressed environment due to its location in this transition region from the dry zone to the semi-arid zone (semi-humid to semi-arid) (figure 5). In general, this region as a whole has been in the backwoods of rural development and settlement except for a few scattered major irrigation schemes situated further south. In the past, the infrastructure development in this region had not progressed to the same extent as that in the NCP and NWP.

For the whole of this semi-arid region, the only stable cascade settlement has been the Bodagama cascade located in the upper reaches of the Malala Oya basin. This has been possible because of its proximity to the ancient medium tank settlement of Migahajandura which boarders the main Malala Oya. The Hambantota-Migahajandura road was the main 
ancient cart tract which linked this area to the center of administration in the Hambantota district. The northern segment of this cascade has been closely linked to the Tanamalwila township which was an important junction in the two main highways of this region.

The main enterprise of the sparsely scattered settlements in this area was rainfed chena cultivation, and their chief staple diet was Kurakkan and other minor millets. Irrigated rice was only a secondary occupation and that too only under medium sized or larger tanks. The other main enterprise was cattle rearing and traditional curd manufacture. The small tanks primarily served as a source of reasonable quality surface water for domestic use and cattle needs, and secondarily for rice irrigation if rains were good. From the early 1920s to the late 1960s, rainfed cotton cultivation on chena land was the chief commercial activity, which provided farmers with a modest but stable income. Bodagama, due to its location was an important cotton collection center. With the disintegration and collapse of the supporting services as well as the guaranteed purchase of their cotton harvest, this useful enterprise has completely disappeared. Irrigated rice is confined to the large and medium tanks within this cascade (described in chapter 3).

Government support and interventions from the early 1970s up to now have been predominantly for the restoration of the medium and larger tanks within this cascade and the adjacent cascades within the Malala Oya basin. Food crops that fetch a good market price have replaced cotton as cash crops. Green gram or mung bean was the most popular rainfed cash crop up to the time that liberal imports of this commodity was permitted.

The last 10 years had seen more investment on the rehabilitation of the smaller tanks under the IRDP with NORAD aid, combined with a significant improvement in road and other service infrastructure. The most recent Mau Ara diversion to the Malala Oya basin will augment the water supply to three major cascades, namely the Bodagama, Ranmudu Ara and Siyambalagaswewa cascades.

The Gam Udawa program of the 1980s and 1990s has significantly helped to improve the infrastructure in this region by improving roads, school buildings, health services and rural housing. Supply of good quality drinking water has proved a problem because of the high salinity and fluoride content in groundwater. Rural electrification is still limited to areas traversed by major road networks and , at present, it serves only a few tank village settlements located within a close distance to the major road network. The pace of change is, however, now picking up rapidly within the area and two garment factories have also been recently set up. Several non-governmental organizations are also operating in this area attending to health, sanitation, education and drinking water supply needs of the people.

A complete transformation of the traditional living styles that were based mainly on rainfed chena cultivation are now giving way to more diversified forms of occupation and life styles, with the added advantage of much more nonfarm activities in nearby growth centers. Unfortunately, however, the earlier assured short seasonal work at the Government owned Hambantota salterns is no longer available after privatization, and this has deprived them of a traditional source of nonfarm employment. Health, education and banking facilities are also being improved at a rapid rate, all of which is helping the diversification of employment within this region. 


\section{General Discussion across All Cascades}

From the kind of changes that have taken place in these 5 cascades, it can be concluded that both the nature and pace of recent changes have shown a marked difference between cascades in the NCP, NWP and SP. There is also a marked contrast in the state of development in each of these cascades at the turn of the nineteenth century and also again by the middle of the twentieth century. Those in the SP were the least developed and advanced, while those in the NWP were more developed and advanced because they had received attention and investment over a longer period and were therefore in a better stage of development. The state of development of those in the NCP had been strongly influenced by their proximity to administration centers or newly developing townships.

Almost all the bigger and medium sized tanks across all cascades have now been rehabilitated by the Government over the last 20 years, using both bilateral and multilateral donor assistance. The road infrastructure has been greatly improved and both internal and external linkages to trade and commerce have been improved. So have the opportunities for nonfarm employment outside the cascade area.

Housing, educational and health facilities have also undergone considerable of transformation over the last twenty years, especially in the four cascades of the NCP and NWP. Better quality drinking water has been made available by means of tubewells over the last 15 years in areas with good groundwater quality.

On the whole, the quality of life within the cascades has markedly improved over the last two decades and the regular tank rehabilitation and road maintenance work carried out by the different state agencies has helped to keep the population contended within the village tank settlement. Off-farm sources of employment are also becoming increasingly available in the new garment factories and other small scale enterprises that are developing in the respective regions. Thus, the drift to urban areas in search of employment is greatly reduced and even prevented.

Private sector investment is mainly for domestic housing and comes from people having employment in the Middle East on regular contract basis. Small scale entrepreneurship activity is at a very primordial stage. A significant amount of money is siphoned into the village, both for consumption and housing improvement, by youth employed in the armed services.

In the long run, it would be economically advantageous for the state to continue to make these regular modest investments in tank rehabilitation and infrastructure development, because of the new dynamism of self advancement that is taking place within the cascades. 


\section{CHAPTER 7}

\section{Present and Future Issues Facing Small Tank Cascade Systems}

The present and future issues facing small tank cascade systems are discussed in relation to the following areas:

1. Population pressure

2. Hydrological endowment

3. System stability

4. chena cultivation

5. Rainfed paddy cultivation

6. Agrowell development

7. Pollution, lotus growth and fishing

8. Elephant menace problems

9. Government efforts and investments

10. Political interference

\subsection{Population Pressure}

A general estimate of the rate of population increase can be obtained from the figures given below (table 8 and 9) for the more important larger tanks under each cascade, and, wherever data was available, for the total cascade as well.

\section{Cascade 1}

A two to three fold increase in the number of families over a period of around 100 years can be observed. It was found that for the whole cascade 1,011 families have 676.63 ha of paddy land (table 8). 
Table 8. Population figures for cascade 1.

\begin{tabular}{lcc}
\hline Tank & $\begin{array}{c}\text { Number of families } \\
\text { in } 1900\end{array}$ & $\begin{array}{c}\text { Number of families } \\
\text { in } 1998\end{array}$ \\
\hline Pihimbiyagollawa & 70 & 132 \\
Thambalagollewa & 80 & 155 \\
Palipothana & 20 & 60 \\
Wewalketiya & 12 & 128 \\
Balahondawewa & 70 & 137 \\
\hline
\end{tabular}

\section{Cascade 2}

In the whole Mahakanumulla cascade (table 9) about 400 families in the 1900s has grown to 1,600 families which now have among them only 574.65 ha of paddy land. In the Thirappane cascade it was found that 342 families have 77.95 ha of paddy land.

Table 9. Population figures for cascade 2.

\begin{tabular}{lcc}
\hline Tank & $\begin{array}{c}\text { Number of families } \\
\text { in } 1900\end{array}$ & $\begin{array}{c}\text { Number of families } \\
\text { in } 1998\end{array}$ \\
\hline Meegassagama & 7 & 65 \\
Thirappane & 10 & 60 \\
Mahakanumulla & 24 & 84 \\
\hline
\end{tabular}

\section{Cascade 3}

Under the maha Nanneriya tank alone, which can be considered the main hub of this cascade, there were 50 families in 1930 and this has now increased to 650 families. For the whole cascade which has a total command area of 612.70 ha, the total number of land holding families is 1,912. Much of the old chena land adjoining the road is being converted to homesteads because of land demand for housing.

\section{Cascade 4}

Under the Hidogama tank in this cascade there were 60 households in the 1930s and this has now increased to around 400 households. In the maha Kirinda tank it has increased from 20 families to 200 families within the same period. Within the whole maha Girilla cascade, which has a command area of 425 ha, there are 1,400 landholding families.

\section{Cascade 5}

There was very little population in this area at the beginning of the twentieth century compared to the other cascades. In the Bodagama tank village there were 20 families in 1900 
which has now increased to 250 families and in the Palugaswewa tank village there were 11 families in 1920 which has now increased to 70 families.

On the other hand in the Angunakola maha Wewa, which was restored in 1958, the number of families settled by the Land Commissioners' Department was 60, but now only 30 families remain.

Although the population in this area has increased, there was no preference for people to restore abandoned tanks and settle around them like in the NCP. Since people depend more on rainfed agriculture and hold on to nonirrigated upland in preference to irrigated paddy land.

The population pressure in the first four cascades has now reached a critical limit both in respect of the total number as well as the extent of irrigable land owned by each family. It will therefore be difficult for these cascades to absorb any further increase in population except for residential purposes.

\subsection{Hydrological Endowment and System Stability}

In the first two cascades the ratio of cascade area to waterspread area is more than 8.0; and the ratio of tank capacity to command area is around 2.0. Hence these have a good hydrological endowment. The cropping intensity for the maha season for tanks located along the main valley is around 80 percent and for those on the bigger side valleys it is around 60 percent.

In cascade 3, the hydrological endowment for the maha season is very good, and generally all tanks within this cascade fill up during the maha season. In contrast, there is very poor hydrological endowment for the yala season. Consequently, this cascade enjoys a very stable maha cropping intensity. The maha Nanneriya tank, and the Ihalagama and Molewa tanks report a 100 percent cropping intensity for the maha season for the period from 1988 to 1998 .

In cascade 4, maha Girilla, because of the higher amount of bimodal rainfall received during the year, hydrological endowment is very good. However, this endowment is somewhat minimized by the very high tank density and also by the high degree of silting in the smaller tanks. The maha cropping intensity in the main valley is 100 percent, and in the side valleys it is between 50 to 85 percent. The yala cropping intensity is highly variable and ranges from 50 to 80 percent, the main reason being the over expansion of the command area under the smaller tanks and also the low storage volume resulting from cumulative silting of the tanks.

In cascade 5 there is significant cultivation activity only under five tanks, namely Bodagama, Palugaswewa, Weheragala, Angunakola mahawewa and maha Aluthgam Ara. Because of poor hydrological endowment, the cropping intensity for the maha season over a 10 year period has barely achieved 30 percent in the best of these five tanks. In the other 4 tanks, there is a period of 2 to 3 successive years when no cultivation was possible because of inadequate runoff.

Thus, there is little or no further potential for improving present system stability in all 5 cascades by means of improving hydrological endowment, except through better water management. 


\section{3 chena Cultivation}

It should be recognized that chena cultivation received priority over irrigated rice in small tank cascade systems in agriculture of the medieval period. Farmers started their paddy cultivation in late November only after completing the main chena cultivation activities. Under the low population pressure that prevailed up to the early part of the twentieth century a very sustainable form of land use was achieved as long as there was no constraint on the availability of chena land. The traditional chena practices have now been replaced by many new practices including use of chemical inputs, mainly because of a shortage of chena land. Modern chena farming is practiced in a limited form in the first two cascades. It is virtually abandoned in the third cascade due to the shortage of chena land and the Elephant menace. Similarly, it is being replaced by settled rainfed tree-crop agriculture in the fourth cascade.

In cascade 5, Bodagama, chena cultivation is the predominant activity, compared to irrigated paddy cultivation. Traditionally people were accustomed to a staple diet of Kurakkan and other millets grown in the rainfed uplands, in place of rice. Modern chena farming in this cascade retains very few of the traditional practices and the traditional crops are now replaced by market oriented food crops in place of the former subsistence crops. Despite population increase, adequate land is still available for rainfed chena cropping in this area.

As can be observed from the above information, a major transformation in traditional chena cultivation is now taking place. Because of land limitations in the first three cascades the chena cycle is getting shorter and productivity of the land is diminishing. In cascade 5, there is further scope for replacing chena cultivation with settled rainfed agriculture. In the highly populated cascades much of the chena land close to the village tank is being used for domestic housing, aided by the supply of tubewell drinking water. There are little or no signs of a further intensification of chena farming in most of the cascades that were studied. In fact, the traditional form of chena cultivation is receding from the agricultural scene very fast.

\subsection{Rainfed Paddy Cultivation}

Rainfed paddy cultivation proper is really practiced only in maha Girilla (cascade 4) where both rainfall as well as hydrological and landform conditions permit its practice. However, it is grown on "phreatic" paddy lands where moisture supply to the growing crop is augmented by the standing water table which is regularly recharged by the tank water hydrostatic pressure head. There is no truly rainfed "pluvial" rice under any of these cascades-it is only partial rainfed rice that prevails.

In the first three cascades however, and in a part of the fourth cascade, the paddy cultivation on the Akkarawela starts off as a rainfed crop in the initial stages, but it receives irrigation supplies after the crop is well established, especially at the tillering and at the heading stages of the crop.

In sum, there is very little scope for further expansion of rainfed paddy in any of the 5 cascades. 


\subsection{Agrowell Development}

Although there is considerable potential for agrowell development in cascade 1, 2 and 3, the only significant agrowell development that has taken place is confined to 3 minor tanks located in the Mahakanumulla cascade. There are 55 agrowells under the Paindikulama tank, 19 under the Mawathawewa and 15 under the Thorapitiya tank, all located within the Mahakanumulla cascade.

The construction and development of agrowells is not determined solely by hydrogeological consideration as commonly envisioned. There are several other political, economic and management factors that play a role in driving this new development which has been gaining ground over the last $10-15$ years.

Grants and subsidies, on very generous terms are made available through line agencies that are controlled by the political hierarchy that functions within the Anuradhapura district. Concessionary loans are made available to farmers, not on the basis of feasibility studies, but more on competition among higher level politicians in order to boost their own performance credentials.

The poorer farmers find it difficult to incur such a big investment of more than Rs 40,000.00 in the construction of an agrowell and a further Rs 10,000.00 on the purchase of pumps and accessories. Wherever a middleman or Mudalali (trader cum moneylender/ middleman) can facilitate the whole process, including that of obtaining a loan, the farmer is willing to bond his output to this Mudalali for a specific number of cropping seasons.

It should also be noted that agrowell farming is very definitely an individualistic effort, which cuts across traditional community work in almost all farming operations within a cascade. This naturally gives rise to various sources of conflict within the farming community. The spread and performance of agrowells across this district has been highly variable and it is now reported that a significant number of agrowells are being abandoned or else are going out of production. The attractive prices for these high value vegetables and condiment crops are no longer available. There is also uncontrolled over production of some crops like okra, which is pushing prices down.

There is another danger-the viability of farming under the agrowell irrigation systems is being seriously eroded. Though funds and technical guidance for well construction are often provided by state officials, there is a gap in providing appropriate farm planning. This leads to losses that tarnish farmer faith in agro-well irrigated farming. The end result is early abandonment of agrowells.

A further serious hazard is that of exceeding the critical density of agrowells that are hydrologically possible within a cascade. Proven and tested criteria are now available for determining the optimum spacing and agrowell densities in the different hydrogeological environments in this region-these should be enforced and practiced. Already in 15 out of 351 cascades in the Anuradhapura district, the upper critical limit of agrowells has already been exceeded. This gives a sure warning against the indiscriminate expansion of agrowell cultivation programs in the NCP. 


\subsection{Pollution, Lotus Growth and Fishing}

Pollution of water in the tanks has not reached any significant level, except for occasional complaints of skin irritation after tank bathing towards the end of the dry season. Localized pollution from the discharges of illicit liquor manufacturers is reported in cascade 3 . However, no analytical results are available from sampled tanks in order to ascertain the nature of what the pollutants could be. In cascade 4, the smaller tanks at the uppermost head end of the valley receive a fair amount of agrochemical washouts. There is no monitoring program being conducted by any agency in this region in order to ascertain the nature of the pollutants.

Lotus growth is present in almost all the tanks in cascades 1,2 and 4. There is very little lotus growth in cascade 3 because of the higher water depth of the tank. The density of lotus growth is highest in cascade 4 because of the shallow depth of the tank cascade caused by silting as well as by the prevalence of water almost throughout the year. In the drier regions, the tanks dry out completely in the dry season and this breaks the cycle of lotus regeneration.

Although there is no organized harvesting of fish at present, there were older traditions of joint harvest of fish by the whole village and a proportionate sharing of the catch. These practices have broken down, and are partially observed only in one village in the mahakamanulla cascade. Plans are afoot to stock and harvest fish in cascade 4 and 5 under the new inland fisheries development program of the Department of Inland Fisheries. According to Thayaparan (1982) the potential for fishery production in these small tanks is very high and it should therefore be promoted as a feasible economic activity.

\subsection{Elephant Menace}

Around 30 years ago there was adequate forest and jungle areas for elephants to draw their food supplies, and they were not compelled to invade the cultivated chenas and paddy fields. Man and elephant could easily co-exist in this earlier environment where there were adequate resources for both to function without competition. With the dwindling of the free roaming jungle lands that were formerly available for elephant ranging, small herds of pocketed elephants began to intrude into cultivated areas. The elephant menace is most serious in cascade 3. Farmers here have almost given up chena cultivation. This is caused by elephant herds dispersed from the Wilpattu national sanctuary, which now falls within the ethnic conflict zone.

A further problem in cascade 1 and 2 is that elephant scaring was a communal effort which was shared by all, but with the shift to individual commercial chena farming it is difficult for one or two individuals to effectively carry out this task at night time. This is now considered a serious constraint for chena cultivation. Also, the distance to the chena lands from the village settlement has increased and this too acts as a further constraint. 


\subsection{Government Efforts and Investments}

Significant government intervention and investments into improving the physical infrastructure of small tanks commenced during the 1970-77 period when a major emphasis was given for the improvement of the small tank irrigation sector. Under the decentralized government budget, substantial financial allocations were made to political authorities in every district to utilize local labor to the maximum in small tank repair and maintenance. This process picked up after the 1980 period with major investments being made by the World Bank on the Village Irrigated Rehabilitation Project (VIRP) and the subsequent National Irrigation Rehabilitation Project (NIRP) from 1989 onwards. The Asian Development Bank (ADB), International Fund for Agricultural Development (IFAD) and NORAD have also given significant assistance to the different provinces on infrastructure improvement for small tank systems.

All five cascades have benefited in varying degrees through the investment made by the government under various bilateral and multilateral projects. Investments have been made primarily on hardware, namely construction of infrastructure and repair, maintenance and rehabilitation. On an average most tanks have been able to benefit by a rehabilitation of some kind or other every 25 years. This has helped to extend the life of most of the small tank cascade systems but not to increase their productivity in a significant manner.

Some attempts made in the 1980s to improve the software and management under donor assisted projects has proved only partially successful and has yet to show a significant impact. The ADB funded rehabilitation project in the NWP, the NORAD funded rehabilitation project in the SP, and the IFAD funded Participatory Rural Development Project (PRDP) in the Anuraphapura district have all attempted to improve the system management aspects with varying degree of success. These attempts have been a departure from the earlier fixed framework mode and approach to rehabilitation.

Concurrently, considerable investments had also been made by the state on the physical infrastructure of the education, health and communication sectors. These were very visible in each of the five cascades that were studied.

Rural electrification has now been provided to most segments of the 5 cascades, and most homesteads in this rural environment are now using various electrical appliances, including television which has connected them to the national information networks.

\subsection{Political Intervention}

In Pihimbiyagollawa (cascade1), the main political figure for the last 50 years has been the same person and this has had a benign influence. In other cascades the development of infrastructure facilities has been strongly influenced by political intervention. Especially in agrowell allocation there is a strong political bias. In provision of rural electrification, political pressure and patronage play an important role in what area would receive priority. In cascade 3, the parliamentary representative for the area was the Minister of Finance in the 1965-70 government and he was able to make substantial improvements to this cascade during his tenure. 
In Bodagama (cascade 5), in the settlements that were made in the newly restored tanks, the allocation of land were made more on the political affiliation of the selected allottees, many of whom happened to be outsiders, rather than to deserving individuals from within the area. 


\section{Chapter 8}

\section{Synthesis and Conclusions}

A total of around 15,000 small tanks, both operational and abandoned, are found distributed across 70 well defined river basins in the dry zone of Sri Lanka. Approximately 40 percent of these small tank systems are located within the NWP, 26 percent within the NCP, and 10 percent respectively within the SP and NP. Over 90 percent of these small tank systems are clustered into cascades. There is a wide variation in the size-class and geometry of these small tank systems across the dry zone landscape.

Both field studies as well as supporting historical commentaries point to the fact that the construction of and settlement around these small village tanks would have taken place over a long period up to around 1200-1300 A.D. There are a higher proportion of small tanks in an abandoned state found in the SP and the NP. It can be reasoned from preliminary studies that there are different sets of reasons for the abandonment of small tanks in the different regions of the dry zone.

Successive legislative enactments have been made from 1856 in order to revive the operation, maintenance and satisfactory functioning of these small village tanks with varying degrees of success. From 1979, the responsibility for the maintenance of minor irrigation works lies with the Department of Agrarian Services (DAS). This has understandably contributed towards their long term stability and continuity.

Five modal cascades were identified to represent the main agro-morpho-ecological situations that make up the dry zone of this country and the rationale for their selection was explained. There are a total of 185 individual small tanks of varying size located within these five cascades.

The core of this study involved an examination and analysis of certain key features of the traditional small tank cascade systems. These included, (a) the location and design of tank cascade systems in the past, (b) the hydro-system which considers the overall hydrological balance and groundwater conditions, (c) maintenance and tank use which considers past and present practices of maintenance, irrigation methods and tank water use and (d) tank management and integration with local farming systems.

This study suggests that the location of tanks within an inland valley of the cascade was determined more by site features and social factors rather than by hydrological considerations, which perhaps explains the hydrological inadequacy of a significant proportion of these ancient cascade systems. It is also reasoned that the body of expert knowledge and skills that went into the construction of the reputed larger hydraulic structures of that period would have been applied, with some degree of adaptation, to these smaller tank systems as well. 
A key consideration to be borne in mind with regard to the hydrological features of the traditional small tank is that the capture of water in these reservoirs was intended less for irrigated paddy, but more for the needs of human settlement and survival through occasional periods of sustained drought. This is also supported by a recent study of Navaratne (1998) which indicates that irrigation issues make up for only between 10 to 20 percent of the seasonal water yield and that the water use for paddy irrigation under small tanks is therefore marginal.

In the traditional method of tank maintenance prior to the period of British rule, it was the Rajakariya system which drew upon the collective effort of the farmers under the direction of a Velvidane. Major disruptions to this system were caused by the abolition of the Rajakariya system in 1832 by the British administration. Various legislative enactments, with varying degrees of success, have subsequently attempted to restore some aspects of this collective effort by retaining the role of the Velvidane. Although the Velvidane position was later abolished under the Paddy lands Act of 1958, the more recent legislation enacted in 1985 reserves a definite position for the Velvidane in the new FOs.

Apart from irrigation for paddy, tank water is also used for livestock rearing, domestic use and fish harvesting, while the tank bed is also used for other purposes such as cattle grazing and brick making.

The duties of the Velvidane were clearly stated in the Irrigation Ordinance of 1946. At present, while the day to day activities connected with the cultivation of lands under the tank is handled by the FO under the supervision of the DAS - the Velvidane position is also retained. The Kanna meeting is undoubtedly the most important decision making institution which operates at the tank level. Its scope and functions are clearly defined, although there are several lapses in implementation. However, here again, it is the Velvidane who plays a vital role in the implementation of the Kanna meeting decisions.

Although the main rationale for the Kanna meeting is to make optimum use of the limited and highly variable irrigation supply, many deviations from the agreed decisions made at the Kanna meeting take place. Poor attendance at these meetings and the loosely defined authority of the FO are the main reasons for such deviations. In the five cascades that were studied, it was observed that both the integrity of the Kanna meetings and their implementation functioned at varying degrees of efficiency and inefficiency. It is also observed that despite the presence of the FO, it is the Velvidane system that is the prime functionary within the first 4 cascades, while in cascade 5 it is the village headman.

With regard to integration with the local farming system, both the expansion of the Akkarawela as well as the reduction of chena land that is now available for a greatly expanded population has put severe strains on the traditional integration that prevailed between irrigated lowland paddy and rainfed chena upland. Further disruption has been caused by the advent of the agrowell development system which promotes more individualistic effort in place of traditional communal efforts. The integration with cattle and buffalo free range grazing system persists in a much reduced form, while rudimentary fish harvesting practices have been almost abandoned. 
In the study of these five cascades it was observed that there is a marked difference in the nature and pace of the recent changes that have taken place between the cascades in the NCP, NWP and SP. There is also a marked contrast in the state of development that existed in each of these cascades during the early part of the twentieth century. Almost all the bigger and medium sized tanks across all cascades have benefited from government assisted rehabilitation. Road infrastructure, housing, educational and health facilities have improved vastly and better quality drinking water is also now being supplied. These cascades which were somewhat isolated settlement outposts in the past are now becoming increasingly linked to the main streams of rural-urban trade and commercial opportunities.

On the whole, the quality of life within the cascades that were included in this study has improved greatly over the last 2 decades and this has in turn minimized the drift to city slums. A significant amount of money is being siphoned back to the cascades from money earned from Middle East employment and employment in the armed services. Private sector investment at present is largely limited to domestic housing. It is argued that, economically it would be advantageous for the state to continue to make this modest investment on regular rehabilitation of the physical infrastructure in order to sustain the present dynamism found in these cascades.

Foremost among the issues facing these small tank cascade systems, is the diminishing land per person ratio, and the land to water ratio. A two or three fold increase in population over the last 50 years has been accompanied by a significant reduction in the family holding size of Puranawela, as well as a serious competition for the expanding Akkarawela. As noted earlier, the present hydrological resources of the small tanks cannot meet the expanding needs of the new Akkarawela lands.

Similarly, the availability of new chena land is also becoming severely restricted and most of the former chena land in close proximity to the tanks is now getting converted into settled homestead gardens. Nor is there any scope for further expansion of rainfed paddy cultivation.

The present pace of agrowell development, if allowed to proceed unchecked at the present rate, could lead to disastrous consequences if the optimum well density and spacing is exceeded. The pollution levels and trends of the water in these tanks should be monitored in the future to ascertain the nature and degree of pollution levels.

The elephant menace and political interferences, though of an ephemeral nature, should also be addressed and corrective measures should be recommended.

Declining profits from paddy agriculture with attendant high cost of input services, low paddy prices and uncertainties and unreliability involved in water supply and pest attacks have had a depressing effect in farmer investment in irrigated paddy agriculture, in spite of the government's rehabilitation efforts in small tank systems. If not for the economy based on Middle East remittances and military employment, rural conditions by now would have deteriorated to a very low level. Moreover, rural educated youth are no more interested in agriculture because of its low profitability and also due to the lower status it now commands within rural society. All these factors indicate that the answer lies in the provision of nonfarm income from within and outside the villages. This requires rapid skill development, vocational training, etc., so that the recipients of these skills could take up employment in addition to having farming as a supplementary source of income. In other words, income lost from chena cultivation has to be supplemented through off-farm income giving them a decent income level for sustenance within the village environment. 


\section{Postscript}

\section{The Way Forward}

Based on rainfed chena cultivation, lowland rice cultivation, homestead mixed garden farming, cattle grazing and herding, tank fish harvesting and food gathering, a traditionally selfsufficient life style was maintained in the past. This contented and inward looking life style was in equilibrium with tank based village settlements.

This situation has undergone radical change over the last 150 years and the main production systems are now linked in many ways to external supplies and market forces. As a result, the earlier self-sufficient subsistence equilibrium no longer prevails and many imbalances are now apparent. Due to chena lands being converted to rainfed settlements a high degree of land degradation, soil erosion and tank siltation has taken place. The former equilibrium maintained between tank capacity, irrigated area and tree covered catchment area have also been severely altered. This has resulted in severe stress and conflict arising in lowland irrigated rice cultivation and upland rainfed or chena cultivation.

Furthermore, long established production systems have to be now responsive to the emerging challenges of open market forces. This also makes it difficult to determine realistic production thresholds that should be attained both in respect of rainfed and irrigated cropping systems within these small tank cascade areas.

The dry zone farmer had a typical farming system that was well adapted to crop cultivation under water stress conditions. The Gangoda (home garden), chena and Welyaya (lowland paddy tract) were the components of a well established farming system that sustained the livelihood of dry zone peasantry. The lowland was mostly cultivated with water supply from minor irrigation tanks. However, most of these farmers gave priority to chena cultivation over the other two systems mainly because it was the more stable cultivation practice and also provided most of the family sustenance. Besides, it also provided an assurance against paddy crop failure due to lack of water. Usually, the size of the chena depended on the family size, with $0.80-1.21$ ha as an average. However, due to population increase and pressure on land, the extent of chena has declined with almost no fallow period between two cultivation periods. These changes have reduced the unit land productivity and total household income.

One of the main problems of village tank lowland cultivation is the fragmentation of land and complex land tenure patterns. Both these factors contribute to small sized land holdings (0.1-0.4ha) which are not economically viable to cultivate. Small size of landholdings, seasonal cultivation and uncertain income has all contributed to a low level of investment on minor irrigation. This is evident in a study where 20 minor tanks were evaluated for their performance after rehabilitation (Aheeyar 2001). On an average a family receives Rs 1000.00 per month as income from cultivating paddy under minor irrigation which is not sufficient for the survival of a family of five. Data collected over a 25 year period indicates 
that the yield difference between minor and major irrigation to be approximately $1 \mathrm{t} / \mathrm{ha}$. In view of low yield and less profitability of paddy cultivation in small scale systems, land tenure, land consolidation and land registration should be streamlined and systemized.

As a measure for improving productivity under small tanks, various water management practices have been tested. However, increase in Akkarawela due to legal and illegal settlements have disturbed the water balance in small tanks, thus creating deficiencies in water required for paddy cultivation.

Farm households have three options outside of leaving paddy farming altogether. The three options are: a) increase yields and thereby their farm incomes, b) cultivate high-value crops during the off season or the yala season, c) seek off-farm employment and make paddy farming a part-time occupation.

Part-time paddy farming is an important development that must be comprehended, if realistic and economically viable policies for raising production and productivity in paddy farming are to be designed.

The rationale for part-time paddy farming arises due to the highly uneven distribution of labor over the cultivation period. Apart from the peak periods of farm activity, a good proportion of family labor remains unutilized for many days of the year, if the sole occupation is paddy farming. These factors are intensified when the holding is smaller in size. The push factors for this transformation are: the cost price squeeze of paddy farming as well as the increasing cost of living. The pull factors are: full time employment in more remunerative occupations in or outside the cultivation area and that village youth do not wish to be employed in paddy farming.

An important aspect linked to this issue is the changing parameters which have an impact on sustainable productivity improvements in agricultural lands due to ineffective tenurial arrangements, in particular the existing property rights systems which constrain and act as barriers against private sector investment in rural agricultural development. Voluntary land consolidation included in the Paddy Lands Act of 1958 failed to register any impact in improving the problem of scattered agricultural holdings, nor did government policies address the subject of land fragmentation in private lands as a priority issue for effective solutions. Over the years, attempts made by respective governments to create and sponsor new cultivation rights by handing over uncultivated private lands to village cultivators through emergency regulations also created distortions in the structure of property rights. As a result, the leasing of cultivable lands for commercial and other economic enterprises was viewed with suspicion by landowners for fear of losing the land altogether. Confusion thus created in the land market was further compounded by a very inefficient and outdated system of deeds registration, which is an operation to provide titles to private lands. The government has however taken steps now to initiate measures to institute a more effective system of title registration, which would replace the registration of deeds and assure the public with a government guarantee for a safe and secured title for execution of land transfer and also eliminate litigation on ownership titles. This effort must be strengthened and enforced to achieve the desired objectives.

In order to balance the production thresholds for different cascades with the degree of hydrological endowment of the cascade, it is essential to recognize the range of values of the catchment area-water spread area, command area and mean cropping intensity of the various cascades. It is against these values that the agricultural production threshold of a 
cascade could be properly determined - the existence of a wide range of variation should be recognized. Based on the empirical body of data now available, it is possible to broadly quantify the contribution made to rainfed food crops and irrigated paddy across the range of hydrological endowments of the cascades that are distributed across this landscape.

One significant development that has taken place in the NCP in recent times has been the construction of agrowells under numerous small tank command areas. It must, however, be clearly borne in mind that this shallow "Regolith" aquifer is restricted to definite landscape positions along the main axis of inland valleys and it is also of limited quantity. There are now well proven guidelines that have been worked out for spacing and density of agrowells within this "Regolith" aquifer and these guidelines should be strictly adhered to in order to prevent over exploitation of this limited, but very precious resource. 


\section{REFERENCES}

Abeyratne, E. 1956. Dryland farming in Sri Lanka. Tropical Agriculturist 112: 191-229.

Abeysinghe, A. 1982. Minor irrigation in Sri Lanka, Parts 1 \& 2. Economic Review.

Aheeyar, M. M. 2000. Socio-economic aspects of small tank systems. Proceedings of National Science Foundation Workshop. University of Peradeniya, Kandy, Sri Lanka.

Arumugam. 1952. Development of village irrigation works. Colombo, Sri Lanka: Department of Irrigation.

Ariyabandu, R. de S. 1993. Impact assessment of the Anuradhapura agrowell program. Colombo, Sri Lanka: Agrarian Research and Training Institute.

Brohier, R. L. 1935. Ancient irrigation works of Ceylon. Colombo, Sri Lanka: Government Press.

Begum, S. 1985. Minor tank water management in Sri Lanka. A.R.T.I. Paper 39. Colombo, Sri Lanka: Agrarian Research and Training Institute.

Cook, E. K. 1935. Ceylon, its geography, resources and people. Colombo, Sri Lanka: University of Colombo.

COWI. 1993. Master plan for water supply in Anuradhapura district. Colombo, Sri Lanka: National Water Supply and Drainage Board.

de Silva, C. S.; N. Fernando; R. Sakthivadivel; and D. Merrey. 1999. Managing groundwater in hard-rock areas through agrowell design and development. Water Resources Development 15(3): 333-348.

Dharmasena, P. B. 1992. Magnitude of sedimentation in village tanks. Tropical Agriculturist 148: 97-120.

Dharmasena, P. B. 1994. Sedimentation and desiltation of minor tanks. Irrigation Research Management Unit Seminar, July 1994 Irrigation Department, Colombo, Sri Lanka.

Gunawardana, R. A. L. H. 1984. In transformation of the agricultural landscape in Sri Lanka and South India. Kyoto, Japan: Kyoto University.

Hunting Survey Corporation. 1963. Report on fifteen river basins. Colombo, Sri Lanka: Survey Department.

Ithakura, J.; and C. Abernethey. 1993. Water management in a tank cascade irrigation system in Sri Lanka. IIMI Working Paper 24. Colombo, Sri Lanka: International Irrigation Management Institute.

Ievers, R. W. 1899. Manual of the north central province. Colombo, Sri Lanka: Government Printer.

IIMI (International Irrigation Management Institute). 1994. IIMI-SLFO (Sri Lanka Field Operations) guidance package for water development of small tank cascade systems. Colombo, Sri Lanka: International Irrigation Management Institute.

IWMI Studies. 1996. Natural resources management study of North Central Province. Report to ADB.

Jayasekera, A. M. 1997. Inland fisheries development. Economic Review 23.

Kannangara, R. P. K. 1984. Rainfall probability map of north central province. Journal of Soil Science 5:8093.

Kenderagama, K. M. A. 1994. Salinity status of water in agrowells in the Anuradhapura district. Proceedings of Annual Sessions of the Sri Lanka Association for the Advancement of Science.

Leach, E. R. 1980. Village irrigation in dry zone of Sri Lanka. In Irrigation and agricultural development in Asia: Perspestives from the social sciences, ed. E. W. Coward. Ithaca, USA: Cornell University Press.

Mendis, D. L. O. 1986. Evolution and development of irrigation eco-systems in ancient Sri Lanka. Transactions of the Institute of Engineers Sri Lanka 1:13-29.

Madduma Bandara, C. M. 1985. Catchment ecosystems and village tank cascades in the dry zone. Dordecht, Holland: Riedel Publishing Company. 
Navaratne, W. M. U. 1998. Water balance study for improving irrigation efficiency in minor tanks. MPhil Thesis. Post Graduate Institute of Agriculture. Peradeniya, Sri Lanka: University of Peradeniya.

Needham, J. 1971. Science and civilization Vol. 4, Part 111. Cambridge, UK: Cambridge University Press.

Parker, H. 1907. Ancient Ceylon. London: Lucas.

Panabokke, C. R.; and R. Kannangara. 1975. The identification and characterization of the agroecological regions of Sri Lanka. Proceedings of Section B Sri Lanka Associsation for the advancement of Science 31: 3-49.

Panabokke, C. R. 1999. The small tank cascade systems of the Rajarata, their settings, distribution pattern and hydrography. Colombo Sri Lanka: mahaweli Authority Of Sri Lanka - International Irrigation Management Institute.

Ponrajah, A. J. P. 1982. Design of irrigation headworks for small catchment. Colombo, Sri Lanka: Department of Irrigation.

Ratnatunga. P. U. 1979. Sri Lanka wewas and reservoirs album. Colombo, Sri Lanka: Sri Lanka Freedom from Hunger Campaign.

Roberts, M. 1980. Traditional customs and irrigation development in Sri Lanka. In Irrigation and agricultural development in Asia: Perspestives from the social sciences, ed. E. W. Coward. Ithaca, USA: Cornell University Press.

Silva, M.; and A. Vidanapathirana. 1984. Major irrigation settlements in Sri Lanka. Sri Lanka Journal of Agrarian Studies 5(2):1-11.

Somasiri, S. 1991. Water conservation in small tanks. Tropical Agriculturist. 141:1-20.

Somasiri, S. 1992. Irrigation potential of minor tanks. Tropical Agriculturist. 149:41-58.

Sakthivadivel, R.; N. Fernando; and C. R. Panabokke. 1996. Nature of small tank cascade systems and framework for their rehabilitation. IIMI Country Paper 13. Colombo, Sri Lanka: International Irrigation Management Institute.

Sakthivadivel, R.; N. Fernando; and J. D. Brewer. 1997. Rehabilitation planning for small tanks in cascades. IIMI Research Report 13. Colombo, Sri Lanka: International Irrigation Management Institute.

Tennakoon, M. U. A. 1986. Drought hazard and rural development. Colombo, Sri Lanka: Central Bank of Ceylon, Sri Lanka.

Tennakoon, M. U. A. 1995. Cascade or "Ellangawa." Personal communication.

Thayaparan, K. 1982. The role of seasonal tanks in fisheries development. Inland Fisheries

1:133-167.

Weerawardana, I. K. 1986. Irrigation laws and the peasant. Economic Review. 


\section{Annex}

Number of small tanks within each river basin

\begin{tabular}{|c|c|c|c|c|c|}
\hline Province & $\begin{array}{l}\text { basin } \\
\text { ber }\end{array}$ & $\begin{array}{l}\text { Name of river } \\
\text { basin }\end{array}$ & $\begin{array}{c}\text { Number of } \\
\text { functional } \\
\text { small } \\
\text { tanks }\end{array}$ & $\begin{array}{c}\text { Number of } \\
\text { abandoned } \\
\text { small } \\
\text { tanks }\end{array}$ & $\begin{array}{c}\text { Total } \\
\text { number of } \\
\text { small } \\
\text { tanks }\end{array}$ \\
\hline \multirow[t]{20}{*}{ Northern } & 70 & Churiyan Aru & - & 14 & 14 \\
\hline & 71 & Chavar Aru & 1 & 19 & 20 \\
\hline & 72 & Palladi Aru & 1 & 10 & 11 \\
\hline & 73 & Manal Aru & 20 & 56 & 76 \\
\hline & 74 & Kodalikallu Aru & 19 & 28 & 47 \\
\hline & 75 & Per Aru & 41 & 114 & 155 \\
\hline & 76 & Pali Aru & 3 & 6 & 9 \\
\hline & 77 & Maruthapillay Aru & 3 & 5 & 8 \\
\hline & 78 & Teravil Aru & 6 & 9 & 15 \\
\hline & 79 & Piramenthal Aru & 6 & 7 & 13 \\
\hline & 80 & Methali Aru & 12 & 9 & 21 \\
\hline & 81 & Kanakarayan Aru & 57 & 98 & 155 \\
\hline & 82 & Kalwalappu Aru & - & 3 & 3 \\
\hline & 83 & Akkarayan Aru & 25 & 22 & 47 \\
\hline & 84 & Mandakal Aru & 17 & 22 & 39 \\
\hline & 85 & Pallavarayankaddu & 10 & 24 & 34 \\
\hline & 86 & Pali Aru & 33 & 86 & 119 \\
\hline & 87 & Chappi Aru & 2 & 6 & 8 \\
\hline & 88 & Parangi Aru & 176 & 183 & 359 \\
\hline & Tank & Nay Aru + Giants Tank & 176 & 95 & 271 \\
\hline Total & 21 & & 608 & 816 & 1,424 \\
\hline \multirow{6}{*}{ North Central } & 67 & Yan Oya & 303 & 468 & 771 \\
\hline & 69 & Ma Oya & 184 & 170 & 354 \\
\hline & 90 & Aruvi Aru & 1,127 & 726 & 1,853 \\
\hline & 91 & Kal Aru & - & 5 & 5 \\
\hline & 92 & Modaragam Aru & 160 & 281 & 441 \\
\hline & 93 & Kalu Oya (RB) & 321 & 272 & 593 \\
\hline Total & 6 & & 2,095 & 1,922 & 4,017 \\
\hline \multirow[t]{10}{*}{ North West } & 93 & Kala Oya (LB) & 522 & 299 & 821 \\
\hline & 94 & Moongil Aru & - & - & - \\
\hline & 95 & Mi Oya & 719 & 726 & 1,445 \\
\hline & 96 & Madurankuli Aru & 3 & 73 & 76 \\
\hline & 97 & Kalagamuwa Oya & 61 & 128 & 189 \\
\hline & 98 & Rathambala Oya & $\mathrm{x}$ & $\mathrm{x}$ & 288 \\
\hline & 99 & Deduru Oya & 2,467 & 648 & 3,115 \\
\hline & 100 & Karambala Oya & $\mathrm{x}$ & $\mathrm{x}$ & 481 \\
\hline & 101 & Rathmal Oya & $\mathrm{x}$ & $\mathrm{x}$ & 15 \\
\hline & 102 & maha Oya & $\mathrm{x}$ & $\mathrm{x}$ & 33 \\
\hline Total & 10 & & 3,782 & 1,874 & 6,463 \\
\hline
\end{tabular}




\begin{tabular}{|c|c|c|c|c|c|}
\hline \multirow[t]{9}{*}{ Southern } & 13 & Sinimodera Oya & 8 & - & 8 \\
\hline & 14 & Kirama Oya & 192 & - & 192 \\
\hline & 15 & Rekawa Oya & 102 & - & 102 \\
\hline & 16 & Urubokka Oya & 161 & 20 & 181 \\
\hline & 17 & Kachchigala & 136 & 14 & 150 \\
\hline & 18 & Walawe Ganga & 4 & 354 & 358 \\
\hline & 19 & Karagan Oya & 11 & 17 & 28 \\
\hline & 20 & Malala Oya & 29 & 342 & 371 \\
\hline & 21 & Embilikala Oya & 10 & 10 & 20 \\
\hline Total & 9 & & 653 & 757 & 1,410 \\
\hline \multirow[t]{4}{*}{ Uva } & 22 & Kirindi Oya & 11 & 256 & 267 \\
\hline & 26 & Menik Ganga & 5 & 287 & 292 \\
\hline & 31 & Kumbukkan Oya & $\mathrm{x}$ & $\mathrm{x}$ & 81 \\
\hline & 36 & Heda Oya & $\mathrm{x}$ & $\mathrm{x}$ & 55 \\
\hline Total & 4 & & 16 & 543 & 695 \\
\hline \multirow{7}{*}{$\begin{array}{l}\text { Eastern } \\
\text { (North of } \\
\text { mahaweli) }\end{array}$} & 61 & Kantalai Aru & 4 & 96 & 100 \\
\hline & 62 & Palampotta Aru & 1 & 17 & 18 \\
\hline & 63 & Panna Oya & 6 & 53 & 59 \\
\hline & 64 & Pankulam Aru & 6 & 135 & 141 \\
\hline & 65 & Kunchikumban Aru & 18 & 77 & 95 \\
\hline & 66 & Palakutti Aru & - & 2 & 2 \\
\hline & 68 & Mee Oya & 13 & 45 & 58 \\
\hline Total & 7 & & 48 & 425 & 473 \\
\hline \multirow{14}{*}{$\begin{array}{l}\text { (South of } \\
\text { mahaweli) }\end{array}$} & 32 & Bagura Oya & & & 19 \\
\hline & 35 & Wila Oya & & & 65 \\
\hline & 37 & Karanda Oya & & & 95 \\
\hline & 42 & Pannel Oya & & & 21 \\
\hline & 43 & Ambalam Oya & & & 11 \\
\hline & 44 & Gal Oya & & & 191 \\
\hline & 45 & Andelle Oya & & & 47 \\
\hline & 48 & Mandipattu Aru & & & 29 \\
\hline & 49 & Pathantoppu Aru & & & 46 \\
\hline & 51 & Unnichchai Aru & & & 52 \\
\hline & 52 & Mundeni Aru & & & 138 \\
\hline & 53 & Miyangolla Ela & & & 27 \\
\hline & 54 & Maduru Oya & & & 231 \\
\hline & 57 & Bodigolla Aru & & & 45 \\
\hline Total & 14 & & & & 1,017 \\
\hline Full total & 71 & & & & 15,499 \\
\hline
\end{tabular}


Annex figure 1. Main river basin boundaries of Sri Lanka.

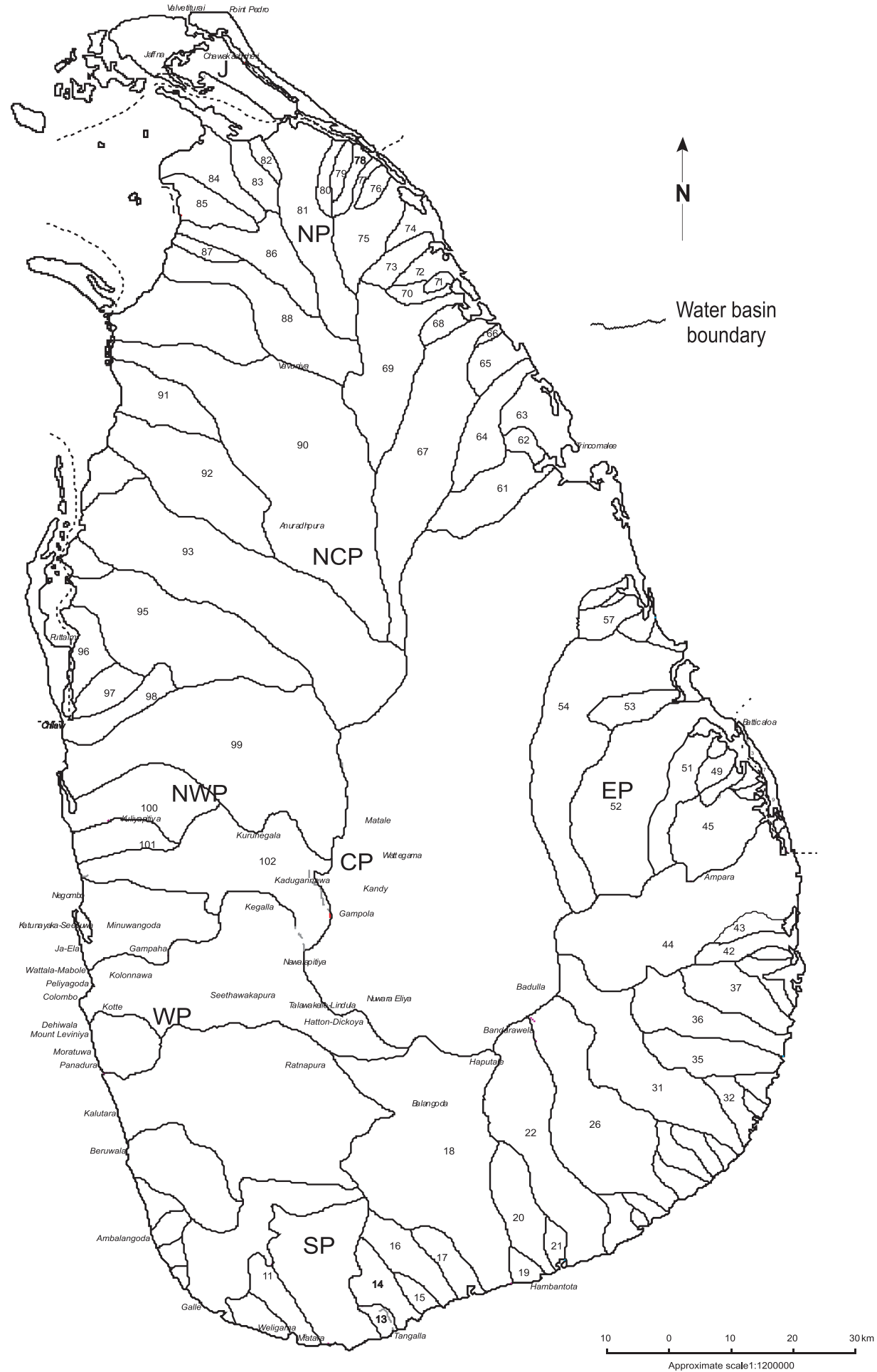


Postaliálalies P. B Box 2075 c colombo sii lank?

\section{Mailing Address}

127, Sunil Mawatha Pelawatta Battaramulla Sri Lanka

Telephione

$+944.17877404,784080$

Pals 1.786584

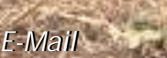

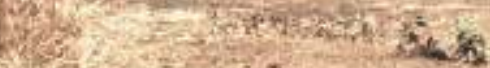

Solita

iwmigctarsorg

Website -

International

FUTURE

httpot/IWWWidumiorg institute 